\title{
1. PALEOCEANOGRAPHY OF THE EASTERN EQUATORIAL PACIFIC DURING THE NEOGENE: SYNTHESIS OF LEG 138 DRILLING RESULTS ${ }^{1}$
}

\author{
Nicklas G. Pisias, ${ }^{2}$ Larry A. Mayer, ${ }^{3}$ and Alan C. Mix $^{2}$
}

\begin{abstract}
The primary objective of Leg 138 was to provide detailed information about the ocean's response to global climate change during the Neogene. Two north-south transects were drilled $\left(95^{\circ}\right.$ and $\left.110^{\circ} \mathrm{W}\right)$ within the region of equatorial divergence-driven upwelling (and thus high accumulation rates and resolution) and spanning the major equatorial ocean current boundaries (and thus recording a high-amplitude signal of the response of the sediment to climatically and/or tectonically driven changes in ocean circulation). The Neogene is marked by a number of well-known climatic and tectonic events (the closing of the Isthmus of Panama, the onset of North Atlantic Deep Water (NADW), the rapid uplift of the Himalayas, the major intensification of Northern Hemisphere glaciation), and the response of the ocean before and after these events was a key focus of Leg 138 drilling.

To address these objectives at the highest resolution possible, the Leg 138 scientific staff developed a number of new shipboard strategies and analytical procedures. These included the real-time analysis of the near-continuous gamma ray attenuation porosity evaluator (GRAPE) and susceptibility profiles produced by the multisensor track (MST) on unsplit cores to monitor core recovery and, if necessary, to modify the drilling strategy to ensure proper offset of coring gaps; the collection of near-continuous color reflectance data on split cores; the logging of the first hole drilled at each site to optimize drilling and sampling strategies for subsequent holes; and the use of multiple continuous records to unambiguously construct complete composite sections for each site. The complete, continuous records provided by the GRAPE (with a temporal resolution of often yr), in conjunction with an excellent microfossil stratigraphy and often excellent magnetostratigraphy, allowed for astronomical tuning of the stratigraphic record and resulted in a set of internally consistent, high-resolution age models that provide a secure, absolute time scale for the past $6 \mathrm{~m} . y$. For the period before $6 \mathrm{~m} . \mathrm{y}$., the absolute time calibration is less secure, but it is still better than any previously offered.

The high-resolution stratigraphic framework of Leg 138 provided new insight into the previously ambiguous tectonic history of the region. By assuming that maximum sedimentation rates along the north-south transect would be expected at the equator, the Leg 138 stratigraphy supports the 1985 work of Cox and Engerbretson, which calls for two different poles of rotation of the Pacific Plate during the interval 0-20 Ma. The Leg 138 plate reconstructions also support several previously hypothesized ridge crest jumps and a slowing of the absolute motion of the Nazca Plate at about $5 \mathrm{Ma}$.

Although Leg 138 data that predates about $13 \mathrm{Ma}$ is limited, the impression that one can gain from these data is that the eastern equatorial Pacific was characterized by relatively high carbonate concentrations and accumulation rates before about $11 \mathrm{Ma}$. This pattern was interrupted occasionally by rapid massive outpourings of near-monospecific laminated diatom oozes that probably represent the formation of massive mats along strong surface-water fronts. The laminated diatom oozes (LDO) continue to be present in the Leg 138 record (many of them being expressed as seismic reflections) until about 4.4 Ma. Carbonate accumulation rates begin to decline slowly between 11 and $9.8 \mathrm{Ma}$, when, at about $9.5 \mathrm{Ma}$, a near-complete loss of carbonate (the "carbonate crash") takes place everywhere in the Leg 138 region (and beyond), except at the westernmost sites close to the equator.

The "carbonate crash" was a time of fundamental change for the eastern equatorial Pacific, and perhaps for most of the ocean basins. Unlike many of the carbonate variations that precede and postdate it, this "crash" represents a major dissolution event whose effects can be traced seismically in the central and western Pacific. The changes in bottom-water chemistry associated with this event (or series of events) appear to be related to the early phases of the closing of the Panama Gateway. The role of NADW initiation and intensification for controlling carbonate accumulation in the eastern equatorial Pacific is still not resolved; however, ocean modeling demonstrates that the closing of the Panama Gateway may also have a direct influence on NADW production. Therefore, the effects of changes in the Panama Gateway sill depth and the production of NADW may be manifested in the history of eastern equatorial Pacific sedimentation.

The "carbonate crash" was followed by a recovery of the carbonate system (except in the Guatemala and Peru basins, which never recovered) that led up to the late Miocene/early Pliocene sedimentation rate maxima, during which equatorial sedimentation rates are as much as five times greater than those of the late Pliocene or Pleistocene. Examination of modern productivity/preservation relationships implies that the sedimentation rate maximum was the result of enhanced productivity. The distribution of eolian sediments and isotopic gradients, along with an analysis of the modes of variance in carbonate deposition over the last 6 m.y., suggest a more northerly position of the Intertropical Convergence Zone (ITCZ), a stronger north-south gradient across the equator, and a more zonal circulation focused along the equator during the time of maximum sedimentation. The mechanisms suggested for these changes in circulation patterns include the response of the eastern equatorial Pacific to the closing of the Isthmus of Panama, as well as a global increase in the flux of $\mathrm{Ca}$ and $\mathrm{Si}$ into the oceans, a possible response to evolution of the Himalayas and the Tibetan Plateau.

In an effort to understand the response of the climate system to external (orbital) forcing, 6-m.y.-long, continuous records of carbonate (derived from GRAPE), $\delta^{18} \mathrm{O}$ and insolation were analyzed and compared. Evolutionary spectral calculations of the variance and coherence among these records indicate that the insolation record is dominated by precessional frequencies, but that the relative importance of the two precessional frequencies has changed significantly over the last $6 \mathrm{~m} . \mathrm{y}$. In general, precessional forcing is not found in the carbonate or isotopic records. In the tilt band, however, a linear response is present between solar forcing
\end{abstract}

\footnotetext{
'Pisias, N.G., Mayer, L.A., Janecek, T.R., Palmer-Julson. A., and van Andel, T.H. (Eds.), 1995, Proc. ODP. Sci. Results, 138: College Station, TX (Ocean Drilling Program).

${ }^{2}$ College of Oceanic and Atmospheric Sciences, Oceanography Admininstration Building 104, Oregon State University, Corvallis, OR 97331-5503, U.S.A.

${ }^{3}$ Ocean Mapping Group, Department of Geodesy and Geomatics Engineering, University of New Brunswick, Fredericton, New Brunswick, Canada E3B 5A3.
} 
and the carbonate and isotope records over some intervals. The carbonate record appears to be tightly coupled to the tilt component of insolation before about $1.9 \mathrm{Ma}$; however, the isotope record does not begin to show sensitivity to orbital tilt until about $4.5 \mathrm{Ma}$, the time of significant changes in sedimentation patterns in the eastern equatorial Pacific. Only during the last $500,000 \mathrm{yr}$ do all frequencies respond in a similar manner; we also see a marked increase in the response of the isotopic record to orbital forcing (including 100,000- and 400,000-yr periods).

\section{INTRODUCTION}

Because of the historic voyage of the original Challenger expedition, the sediments of the equatorial Pacific Ocean have been known to be sensitive recorders of oceanographic change. With the coming of the age of deep-sea drilling and the pioneering work of van Andel et al. (1975), we have come to understand that the sediments of the equatorial Pacific record a complex interplay of ocean chemistry, productivity, climate, and plate tectonics. As our technology improves and our understanding of the ocean/climate system grows, we have returned to the equatorial Pacific for an increasingly closer look at the workings of this complex system. Our most recent effort, Leg 138 , brought a host of new tools and procedures to attack this problem. In this chapter, we try to synthesize some of the strategies used and results gleaned from Leg 138 . We must emphasize, however, that despite the more than $2 \mathrm{yr}$ since the completion of Leg 138, we feel that we have only begun to scratch the surface of Leg 138's treasuretrove of data; our findings are thus preliminary and will certainly be modified and built upon in the years to come.

The primary objective of Leg 138 was to provide information on the ocean's response to global climate change during the Neogene. To address this objective, we chose to drill two north-south transects of sites: one along $110^{\circ} \mathrm{W}$ and another along $95^{\circ} \mathrm{W}$. These transects are within the region of equatorial divergence and thus have high biogenic accumulation rates that will provide high resolution. They also span the major equatorial ocean current boundaries and thus record a highamplitude signal as the accumulated sediment changes in response to climatically and/or tectonically driven changes in the ocean circulation.

The evolution of Earth's climate during the Neogene is marked by a number of global and local events. During the early Neogene, open circulation between the tropical Pacific and Atlantic oceans was possible through the Panamanian Seaway. How this inter-ocean exchange affected oceanic circulation in the eastern Pacific is not well known. Recent numerical modeling results show little oceanic response in the Pacific to this tectonic event (Maier-Reimer et al., 1990), but the model does not include coupled atmospheric circulation. Previous studies of regional sedimentation rates of the equatorial Pacific demonstrated significant redistribution of sediment accumulation rates during the latest Miocene and early Pliocene, which suggests a marked change in oceanic production in response to this tectonic event (van Andel et al., 1975; Pisias and Prell, 1985). However, how this change in sedimentation is related to changing ocean circulation is poorly understood. The drilling transects of Leg 138 provide the necessary paleoceanographic observations that, combined with more sophisticated modeling efforts, should produce significant new insights into this paleoceanographic question. By understanding the relationship between changes in circulation and changes in sediment accumulation, we can also hope to gain insight into the general workings of the ocean/climate system.

During the Pliocene, significant increases in Northern Hemisphere glaciations occurred. Isotopic evidence shows that intensification of Northern Hemisphere glaciation started at about $3 \mathrm{Ma}$, culminating in the first major Northern Hemisphere glaciation at 2.5 Ma (Shackleton et al., 1984, and this volume). This event in the Northern Hemisphere should have had a profound effect on the symmetry of the earth's thermal gradient, which would be reflected in atmospheric circulation patterns (Flöhn, 1978). The Leg 138 transects were also designed to provide a high-resolution look at the response of the equatorial Pacific to these events.

Atmospheric circulation is an important aspect of global climate. Yet, because direct evidence for changes in zonal wind strength is rarely preserved in sedimentary deposits, past variations in zonal wind intensity are poorly understood. Temporal changes in the intensity of atmospheric circulation are reflected in the size distribution of small eolian particles transported in equilibrium with the winds. Eolian particles isolated from pelagic sediments recovered during Leg 138 drilling provide an opportunity to investigate the nature and variability of late Neogene atmospheric circulation intensity in both the Northern and Southern hemispheres. Comparing these records will enable a better understanding of the response and development of the hemispheric asymmetry in atmospheric circulation intensity as the Earth evolved from unipolar to bipolar glaciation.

Specific paleoceanographic questions addressed by Leg 138 drilling include:

1. How did Pacific equatorial circulation evolve through the late Cenozoic as a response to increased global glaciation?

2. Are oceanographic changes hemispherically symmetrical or asymmetrical?

3. What was the nature of the circulation system during the late Miocene when open communication with the Atlantic occurred through the Panamanian Seaway?

4. What was the nature of oceanographic variability during the late Miocene and Pliocene and how does this compare to the Pleistocene (i.e., do the changing boundary conditions modify the sensitivity of the system)?

5. What was the nature of circulation during the Pliocene after the closure of Panama but before the onset of Pleistocene glaciation in the northern hemisphere?

6. How do oceanographic changes affect productivity in the equatorial Pacific surface waters?

7. How are paleoceanographic changes expressed in the physical, acoustic, and color properties of the sediment; can the high-resolution seismic record be a useful paleoceanographic tool?

As we attempt to answer these questions, we hope to provide the important clues needed to understand the cause and nature of oceanographic and climatic variability. The last million years of Earth's history are characterized by large changes in Northern Hemisphere ice cover. These changes have been linked to changes in solar radiation-the Milankovitch hypothesis. The identification of the oceans' and atmosphere's responses is complicated by the presence of both large ice-volume changes and changing external (insolation) forcing. Examination of the ocean system at times before major Northern Hemisphere ice sheets (Question 5) provides the means of determining the effects of external forcing and changes in boundary conditions caused by changes in ice volume. Comparison between the variability and nature of oceanographic conditions during the late Miocene and Pliocene (Question 4) provides information about the sensitivity of the climate system to changes in major oceanic boundary conditions.

Leg 138 has provided a legacy of material that will be analyzed for many years to come; this volume represents only the initial phases of these efforts. In this chapter, we highlight some of the important paleoceanographic results obtained to date but more importantly, we identify some important questions and problems yet to be answered.

\section{REGIONAL SETTING \\ Oceanographic Setting}

The general distribution of surface currents of the eastern equatorial Pacific is illustrated in Figure 1. To a large extent, this circulation pattern reflects the tropical atmospheric circulation and the effects of the change in the sign of the Coriolis force across the equator. A 


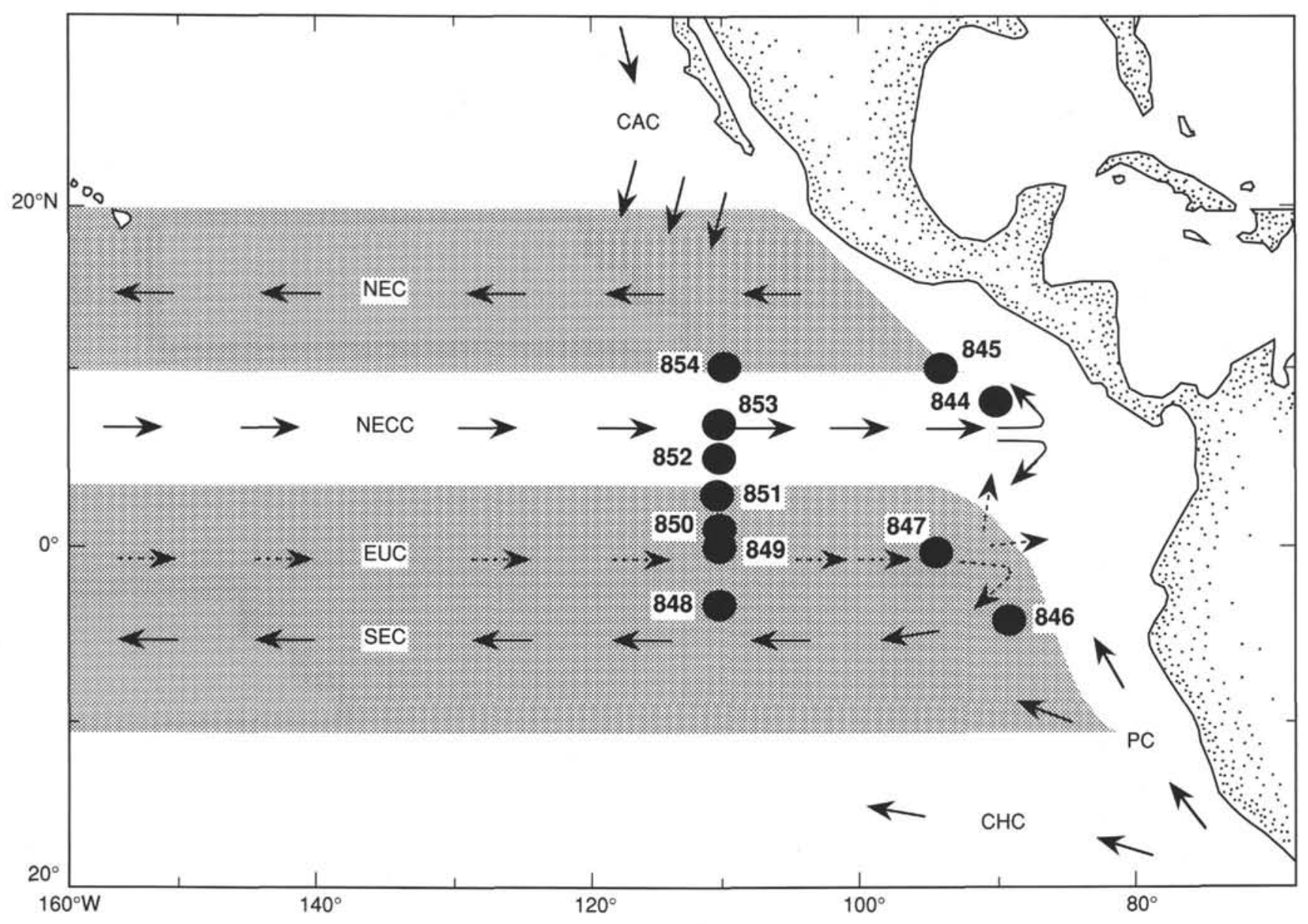

Figure 1. General circulation of the equatorial Pacific showing major surface and subsurface currents. NEC $=$ North Equatorial Current, NECC $=$ North Equatorial Countercurrent, $\mathrm{EUC}=$ Equatorial Undercurrent, $\mathrm{SEC}=$ South Equatorial Current, $\mathrm{CAC}=\mathrm{California}$ Current, $\mathrm{PC}=\mathrm{Peru}$ Current, and $\mathrm{CHC}=\mathrm{Chile}$ Current.

fundamental feature of this circulation pattern is the asymmetry of surface currents north and south of the equator. This asymmetry reflects the general position of the ITCZ, which marks the convergence between the northeast and southeast trade winds. In the present-day climate system, the position of the ITCZ is essentially always north of the equator in the eastern equatorial Pacific. This northerly position, combined with the change in sign of the Coriolis force at the equator, results in the classical picture of surface convergence and divergence. Along the equator, divergence results in a depression in sea-surface topography and a pressure gradient that is balanced by geostrophic flow to the west, both north and south of the equator. This flow is the South Equatorial Current (SEC). Waters from the Peru Current, which carries colder waters from high latitudes into the equatorial current system, and from the eastward-flowing subsurface Equatorial Undercurrent all provide source waters for the SEC.

Seasonal variation in the equatorial current system reflects the seasonal movement of the ITCZ and the seasonal change in the strength of the trade-wind systems. The strength of the SEC reflects changes in the strength of the Southern Hemisphere trade-winds. Wyrtki (1967) describes three patterns of circulation that reflect the movement of the ITCZ.

During August to December, the ITCZ is in its northerly most position at about $10^{\circ} \mathrm{N}$, and the southeast trades are at their strongest. The SEC is at its strongest and the NECC is fully developed. As the NECC flows eastward, it turns in a cyclonic cell around the feature known as the Costa Rica Dome and is a major contributor of water flowing into the NEC south of $20^{\circ} \mathrm{N}$. The California Current turns away from the American coast at about $25^{\circ} \mathrm{N}$ and only contributes water to the NEC north of about $20^{\circ} \mathrm{N}$ (Wyrtki, 1965). This circulation pattern seems to be the most stable pattern associated with a northerly position of the ITCZ (Wyrtki, 1965).

During February to April, the ITCZ is at its most southerly position, the southeast trades are weakened, and the northeast trades are strongest. During this period, the NECC does not develop because of the increased intensity and southerly position of the ITCZ. The SEC is much weakened as a result of the decrease in the southeast trades. The California Current is strengthened during this interval and penetrates to about $3^{\circ} \mathrm{N}$. The California Current is the major contributor of waters in the NEC. Within the Panama Basin and the Gulf of Tehuantepec, two large gyres form. A cyclonic gyre flows around the region of the Costa Rica Dome (at about $8^{\circ} \mathrm{N}, 86^{\circ} \mathrm{W}$ ), and an anticyclonic gyre in the Panama Basin is centered at about $5^{\circ} \mathrm{N}$ and $88^{\circ} \mathrm{W}$.

During May to July, the ITCZ returns to its northerly position. During this interval, however, the California Current is strong and the NECC begins to develop and strengthen. Unlike the period from August to December, the NECC turns northward and contributes waters to the Costa Rica Coastal Current, which flows along the Central American coast. This pattern, according to Wyrtki (1965), is less stable that the first pattern discussed.

The asymmetry found in the distribution of surface currents in the equatorial Pacific can also be seen in the response of these currents to large-scale climate events. Observations of changes in sea level across the equator during El Niño events clearly demonstrate that, although El Niño along the equator is characterized by a weakening of the surface circulation along the equator, off the equator in the NECC and NEC, El Niño is associated with a marked increase in circulation 
(Wyrtki, 1974). Empirical orthogonal function analysis of sea-level records from the central and eastern equatorial Pacific further confirms the asymmetry of the equatorial circulation (Baumgartner and Christensen, 1985). Baumgartner and Christensen (1985) suggested that the equatorial circulation can be viewed as two closed cells, the circulation made up of the South Pacific gyre, including the SEC and the Peru Current, and the cell that includes the NEC and NECC systems. The change in the strength of divergence along the equator and between the NEC and NECC is seen in the out-of-phase response of organic carbon production and flux to the deep sea as observed in sediment trap experiments (Pisias et al., 1986; Dymond and Collier, 1988).

The Equatorial Undercurrent (EUC) plays a critical role in defining the characteristics of the water associated with "equatorial upwelling." Through an analysis of $\Delta^{14} \mathrm{C}$ combined with ocean circulation models, Toggweiler et al. (1991) helped to clarify the complex nature of circulation processes of the EUC. Toggweiler et al. noted that "Water forming the core of the Equatorial Undercurrent in the central Pacific does not reach South America." These waters become entrained into the surface layer west of the Galapagos between $110^{\circ}$ and $95^{\circ} \mathrm{W}$. Bryden and Brady (1985) suggested that the cold-water tongue along the equator results from the entrainment of $20^{\circ}-21^{\circ} \mathrm{C}$ waters from the EUC. Toggweiler et al. (1991) argued that the water that upwelled along the Peru coast comes from the lower layers of the EUC. These waters have T-S properties of $11^{\circ}$ to $14^{\circ} \mathrm{C}$ and $34.8 \%$ to $35.0 \%$. This water is cooler and saltier; it also contains higher nutrients than water upwelled along the equator in the equatorial divergence (Toggweiler et al., 1991).

An important implication of the Toggweiler et al. (1991) study is the connection between sub-Antarctic processes and the equatorial Pacific. The proposed source of the waters in the lower layers of the EUC is in the southwest Pacific, where sub-Antarctic Mode Water is formed. This water has the correct physical characteristics, especially in terms of the $\Delta^{14} \mathrm{C}$ levels. Thus, the inference that the waters that upwell within the Peru Current are derived, in large part, in the subAntarctic, is basically correct. However, the impression that in the present-day ocean this water comes from the sub-Antarctic by ways of the eastern boundary current of the South Pacific gyre is probably, in part, not correct.

This new picture of the source waters for the EUC, combined with the conceptual view of the circulation of the equatorial Pacific, leaves us with a complex interaction of a number of processes that would affect the characteristics of surface waters at Leg 138 sites. Nutrient fluxes to sites within the equatorial band, for example, will reflect the intensity of equatorial upwelling, the strength of advection of waters upwelled along the Peru margin (processes controlled mostly by local wind-stress), as well as the physical and chemical characteristics of these waters, which reflect oceanographic processes, processes that occur nearly a quarter of Earth's circumference away, at much higher latitudes. The chemical characteristics of this water reflect both the chemical composition at its source and also the mixing and chemical alteration that occurs as it flows from the southwest Pacific to the equator and, finally, eastward to the Peru region. Finally, if we call upon links between equatorial Pacific circulation and sub-Antarctic Mode Water, we cannot escape the potential influence of tectonic events and other processes that can result in circulation changes in any of the ocean basins.

\section{Tectonic Setting}

Placing the paleoceanographic records from Leg 138 into a correct geographic framework requires an understanding of the tectonic setting of Leg 138 sites. Sites drilled during Leg 138 are located on three lithospheric plates of the eastern Pacific: the Cocos, Nazca, and Pacific plates. The sites of the western transect (Sites 848-854) are presently on the Pacific Plate. Sites $848,849,850,851,853$, and 854 are thought to have formed at the present East Pacific Rise, whereas Site 852 is near a proposed fossil spreading center that became inactive from 10 to 11
Ma, very close to the basement age of Site 852 (van Andel et al., 1977; Mammerickx and Klitgord, 1982). Backtracking of all sites in the western transect (Fig. 2) is constrained for at least the last 10-11 m.y. by the hotspot reference frame for the Pacific Plate.

A number of possible solutions exist for the absolute rotation of the Pacific Plate. However, the high-resolution chronostratigraphy developed using the method of orbital tuning (Shackleton et al., this volume) provides an important test of proposed rotation parameters for the Pacific Plate. In Figure 3, we plot the sedimentation rates estimated for the sites along the $110^{\circ} \mathrm{W}$ transect vs. latitude. Each frame in Figure 3 represents the interval between the GRAPE events defined by Shackleton et al. (1992). In Figure 3, the paleolatitudes for these sites were calculated using the rotation pole of van Andel et al, (1975). Because of the change in sign of the Coriolis force at the true geographic equator, we assume that the highest sedimentation rate along a north-south transect should be located at the equator where equatorial divergence would always be present.

The rotation parameters of van Andel et al. (1975) result in an over-rotation of the sites. The maxima in sedimentation rates are found south of the equator, especially during the interval of very high sedimentation rates between 7.5 and $4 \mathrm{Ma}$ (Fig. 3 ). If we use the pole of rotation of van Andel et al. (1975), we need to reduce the rotation rate by nearly $50 \%$ to have the maximum sedimentation rates centered at the equator. The discrepancy illustrated in Figure 3 most likely reflects the fact that the rotation parameters, though defined by van Andel et al. (1975) using sedimentation rate patterns, were based on data spanning most of the Cenozoic. The data of van Andel et al. (1975) were of much lower resolution, so that the interval of time of the Leg 138 sites is represented by only one datum.

In Figure 4, the same data as shown in Figure 3 are plotted, but here the rotation parameters of Cox and Engebretson (1985) are used. This rotation scheme is based on dates for hotspot traces that span the late Neogene and, thus, this scheme is much more comparable to the Leg 138 data than the van Andel et al. (1975) study. Using the rotation of Cox and Engebretson (1985), the maxima in sedimentation rates along this north-south transect are now centered at the equator. There are two important differences between the rotation parameters of Cox and Engebretson (1985) and those of van Andel et al. (1975). For the period of the late Cenozoic sampled at Sites 848-854, van Andel et al. defined only one set of parameters $\left(\right.$ pole $=67^{\circ} \mathrm{N}, 59^{\circ} \mathrm{W}, \mathrm{W}=$ $0.83 \% \mathrm{~m} . \mathrm{y}$.), whereas Cox and Engebretson provide two poles for this interval (for the $0-5 \mathrm{Ma}$ pole $=61.6^{\circ} \mathrm{N}, 82.5^{\circ} \mathrm{W}, \mathrm{W}=0.97^{\circ} / \mathrm{m}$.y.; and for the $5-20 \mathrm{Ma}$ pole $=70.3^{\circ} \mathrm{N}, 74.4^{\circ} \mathrm{W}, \mathrm{W}=0.73^{\circ} / \mathrm{m}$.y.). Although the rotation rates for these reconstructions are comparable (average for Cox and Engebretson is $0.79 \%$ m.y. vs. $0.83 \%$ m.y. for van Andel et al.), the pole of rotation for the Pacific Plate differs significantly, especially in terms of the longitude of the pole. Again, these differences most likely reflect the differing temporal resolution of the data used to define these rotation schemes. Based on these results, we use the Cox and Engebretson poles to constrain the absolute rotation of all sites in the eastern equatorial Pacific.

The sites in the eastern transect are located on two oceanic plates. Sites 844 and 845 are on the Cocos Plate, whereas Sites 846 and 847 are on the Nazca Plate. Site 846 is situated on crust formed at the Galapagos Spreading Center and is located on the southern limb of the Carnegie Ridge. Site 847 is located near the boundary between Nazca Plate Crust formed along the Galapagos Spreading Center, which separates the Nazca and Cocos Plate, and the East Pacific Rise, which marks the boundary between the Nazca and Pacific plates. To constrain the backtrack paths of these sites, we use the Pacific/Nazca plate relative motions of Cox and Engebretson (1985): pole $=55.58^{\circ} \mathrm{N}$, $90.10^{\circ} \mathrm{W}, \mathrm{W}=1.42^{\circ} / \mathrm{m} . \mathrm{y}$. The calculations of these relative poles in terms of the absolute poles for the Pacific Plate are given in Table 1. The resulting backtrack paths for Sites 846 and 846 are shown in Figure 2. These paths suggest that these sites have been near their present latitudinal position for their entire history and, thus, provide important reference sections for equatorial circulation history. 


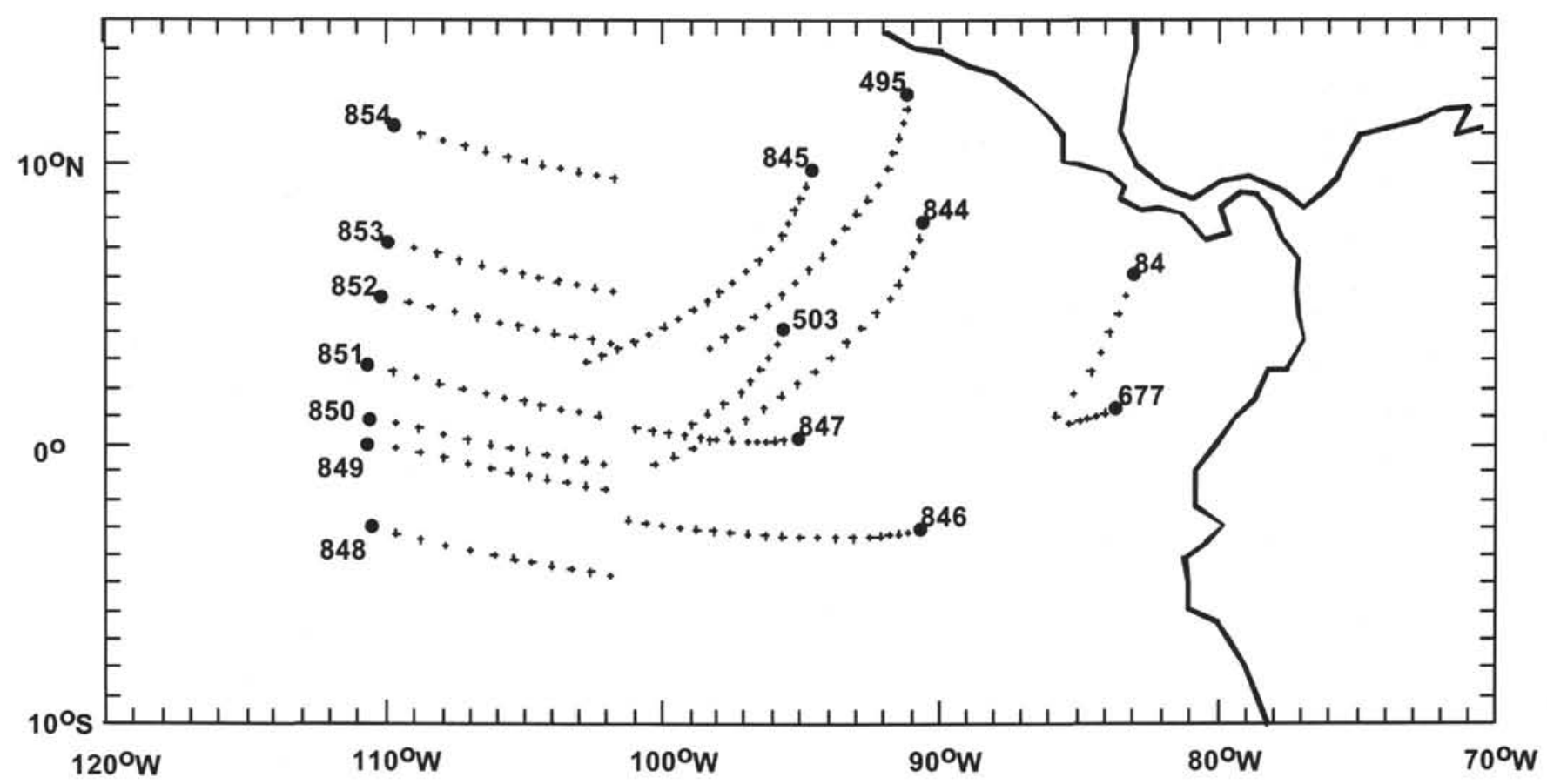

Figure 2. Backtracked paths for Leg 138 sites and other selected sites drilled during earlier ODP and DSDP legs.

The sites on the Cocos Plate ( 844 and 845 ) have the least constrained backtrack paths (see van Andel et al., 1975). The position of Site 844 suggests that it was formed on the East Pacific Rise and its basement age is consistent with the tectonic reconstruction of Hey et al. (1977). Site 845 is located in a region where magnetic anomalies can be mapped (showing a lineated pattern trending northwest/southeast) but cannot be correlated to the marine magnetic anomaly sequence (Klitgord and Mammerickx, 1982). The trend of these anomalies is more westward than anomaly trends produced at the East Pacific Rise. The site is located just east of the Berlanga Rise, which has been interpreted as a fossil spreading center. The unknown history of this feature increases the uncertainty of the backtrack history of this site. For the reconstruction shown in Figure 2, we have used the relative rotation poles for the Cocos/Pacific plate from DeMets et al. (1990), that is, $36.823^{\circ} \mathrm{N}, 108.629^{\circ} \mathrm{W}$ and $\mathrm{W}=2.09^{\circ} / \mathrm{m} . \mathrm{y}$. Again, the calculated absolute pole based on the Pacific pole of rotation is given in Table 1.

In Figure 2, we show the backtrack paths for all Leg 138 sites, as well as a number of other eastern equatorial Pacific drill sites. For each site, we show the backtrack paths at $1-m . y$. increments, with the last point in the path indicating the location of the site when the basement formed. For all sites shown, basement was sampled except for Site 847. We used an estimated basement age of $12 \mathrm{Ma}$ for this site. The rotation scheme used here, for the most part, produces a consistent picture for backtracking of these sites. A number of important implications are relevant for this reconstruction, as follows:

1. The crossing of the rotation path of Site 845 with the path for Site 852 suggests that the East Pacific Rise was farther west at about $3^{\circ} \mathrm{N}$ (location of Site 845 ) than at $2^{\circ} \mathrm{S}$ (location of Site 846 ) at $18 \mathrm{Ma}$. Shown in Figure 2 is the position of Site 845 when Site 852 was at the ridge crest. At $10 \mathrm{Ma}$, the EPR is at about $101^{\circ} \mathrm{W}$, but at $18 \mathrm{Ma}$ the EPR was farther west at about $103^{\circ} \mathrm{W}$, suggesting a ridge jump between these two ages. This is consistent with the hypothesized fossil spreading center discussed by van Andel et al. (1975, fig. 7).

2. The crossing of rotation paths for Sites 844 and 847 would also suggest a ridge jump between the time of formation of Sites $847(\sim 12$ $\mathrm{Ma})$ and 844 ( $19 \mathrm{Ma})$.
3. Sites 846 and $677 / 504 \mathrm{~B}$ have differing basement ages, but they were formed at about the same location.

4. Constant rotation between the Pacific and Nazca plates, combined with the two pole rotation schemes for absolute motion of the Pacific Plate, suggests that the absolute motion of the Nazca Plate significantly slowed at $5 \mathrm{Ma}$.

\section{STRATEGY}

The past $10 \mathrm{yr}$ have seen a veritable explosion of exciting paleoceanographic results, documenting the nature of oceanographic change at increasingly higher resolution. For the most part, these studies (which have allowed us to view the behavior of the climate system at time scales on the order of the mixing and residence times of the major components of the ocean-climate system) have been limited to a select number of high-quality piston cores and, thus, have focused only on the last few glacial cycles. From the outset, the proposers and planners of Leg 138 sought to extend the high-resolution paleoceanographic approach developed for these Pleistocene paleoclimatic studies to the long time series recoverable only with ocean drilling. The application of these high-resolution techniques (mostly spectral) requires continuous, undisturbed sedimentary sections, finely spaced sampling, and a detailed stratigraphic framework. During the course of Leg 138, a number of new shipboard strategies and data analysis procedures were developed to ensure the achievement of these objectives. Although the details of these procedures have been outlined in several papers (Hagelberg et al., 1992; Mayer, Pisias, Janecek, et al., 1992; Shackleton et al., 1992; Hagelberg et al., this volume), we present a brief overview here to place this synthesis into the proper perspective.

The development of the hydraulic piston corer during the late 1970s marked the birth of high-resolution Neogene paleoceanography. Several drilling legs have shown, however, that even when the sedimentary section was sampled using the hydraulic piston corer, significant amounts of the section could be lost between consecutive cores (Heath et al., 1985; Ruddiman et al., 1987; Shackleton et al., 1990; Farrell and Janecek, 1991). The only way to circumvent this problem (and to assure the complete recovery of the sedimentary section) was to drill multiple holes at the same site, with the breaks 

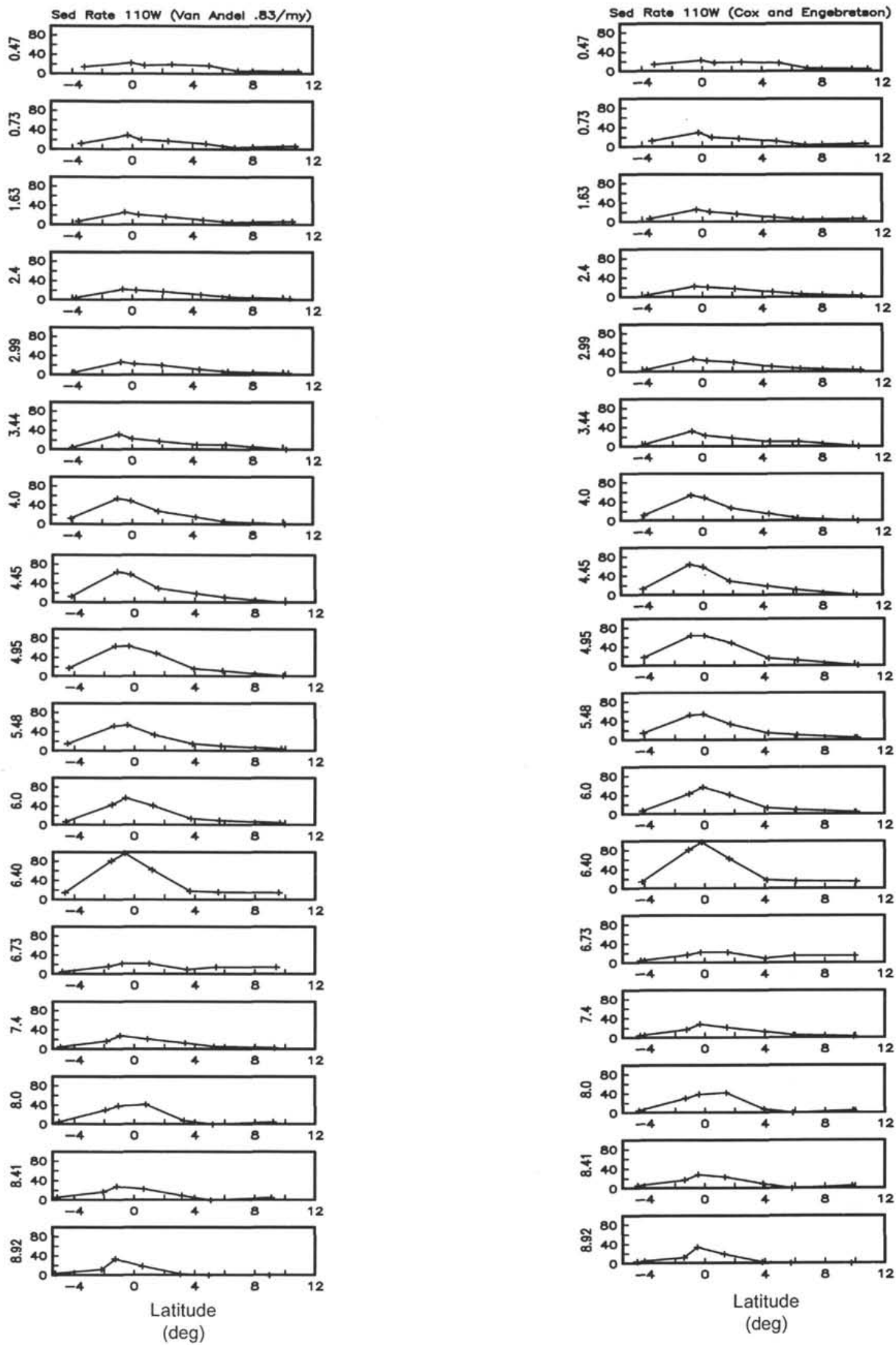

Figure 3. Sedimentation rates at Leg 138 sites along $110^{\circ} \mathrm{W}$. Sedimentation rates were determined between GRAPE events identified by Shackleton et al. (1992). The latitude for each site is calculated according to the rotation scheme of van Andel et al. (1975).
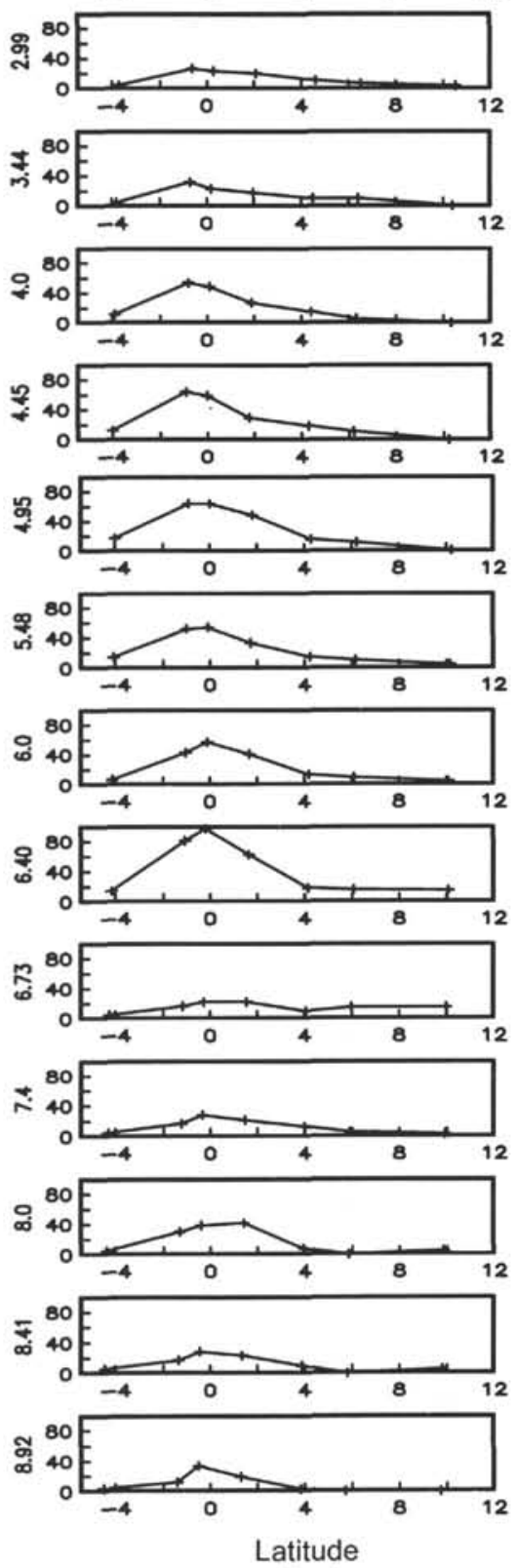

(deg)

Figure 4. Sedimentation rates as shown in Figure 3, but with paleolatitudes estimated according to the rotation scheme of Cox and Engebretson (1985). 
between cores offset. Unfortunately, until the procedures instituted during Leg 138, it was impossible to monitor, while drilling, the success at achieving the proper offset and, thus, the success at recovering a complete sedimentary section.

To monitor the coring process while drilling, we used three types of continuously measured sedimentary properties: (1) the density of the sediment as determined by the gamma-ray attenuation porosity evaluator (GRAPE), (2) sediment magnetic susceptibility acquired with a pass-through Bartington susceptibility ring, and (3) multispectral sediment color reflectance. The GRAPE and susceptibility data were measured at sampling intervals of 2 and $5 \mathrm{~cm}$, respectively, on unsplit cores as soon as the cores reached the shipboard laboratory, using the ODP multisensor track system (MST; see Mayer, Pisias, Janecek, et al., 1992 for details of procedures, and Schultheiss and McPhail, 1989, for a description of the MST). In conjunction with ODP, standard shipboard software was modified to permit the immediate transfer of MST data from the shipboard computer system to the Shipboard Scientific Party. Color reflectance was measured at 3-cm intervals on split sediment cores with an automated tracking system developed at Oregon State University (Mix et al., 1992). The system measures the reflectance of light in 511 wavelength bands that range from the visible to the near-infrared. These data were made available to the Shipboard Scientific Party before the initial description of the split core was completed.

Another strategy aimed at recovering complete sections was our decision to log the first hole drilled at each site (rather than the more conventional practice of leaving logging until the completion of all drilling at a site). This provided the opportunity for the shipboard scientists to obtain an initial stratigraphy for the site and allowed us to compare the GRAPE, susceptibility, and color reflectance data with the downhole logs before drilling the second hole. With an initial stratigraphy and a reasonable idea of what the complete section looked like, we were able to optimize our drilling and sampling strategy in the subsequent holes to assure complete recovery.

By comparing the GRAPE, susceptibility, and color reflectance data from each hole moments after core recovery, we were also able to monitor core recovery in near-real time and, if necessary, to modify the drilling strategy to ensure the proper offset of coring gaps. Through independent comparisons of GRAPE, susceptibility and color reflectance data, we were able to use the data from multiple holes to fill the gaps unambiguously and to construct a complete composite section at a given site (see Hagelberg et al., 1992). During initial shipboard correlation procedures, core data were shifted in their relative position, and not stretched or squeezed; during subsequent post-cruise analyses, more detailed correlations were made among holes, and between the drilling and logging results, using the inverse correlation techniques of Martinson et al. (1982). Once the detailed interhole correlations were made, the records from adjacent holes were "stacked" to produce continuous, 6-m.y.-long time series with temporal resolutions of less than $1000 \mathrm{yr}$ and a common depth scale for all sites (Hagelberg, this volume).

The high-resolution objectives of Leg 138 required not only the collection of continuous sections, but also the development of a stratigraphic framework that would allow us to explore the nature of oceanographic and climatic variability on time scales of a few thousand years. Our initial shipboard stratigraphy was based on the excellent microfossil records preserved in the sediments of the eastern equatorial Pacific (in general, all microfossil groups were present), combined with less consistent, but often excellent, sections of magnetic polarity reversals (see Schnieder and Meynardier et al., both in this volume). The age model used for shipboard work was a modified version of that of Berggren et al. (1985) with a small number of datum levels redated according to the magnetostratigraphy obtained from Sites 844 and 845 (see "Explanatory Notes" chapter in Mayer, Pisias, Janecek, et al., 1992). The result was a fairly self-consistent set of datum levels that provided the age models presented in Shackleton et al. (1992).
The focus of Leg 138 drilling on regions of high sedimentation rate known to have pervasive lithologic cyclicity, however, offered the possibility of reliably detecting orbital signals in the sediments and, thus, refining the stratigraphies through astronomical tuning. The continuous records of changes in saturated bulk density that are measured with the GRAPE have been shown, in the central equatorial Pacific, to be representative of cyclic variations in the percentages of the climatically sensitive biogenic opal and calcium carbonate and, thus, to contain a strong imprint of variations in Earth's orbital geometry (Mayer, 1991). Shackleton et al. (this volume) have taken the stacked composite GRAPE records of Hagelberg et al. (this volume) and compared the cyclicity contained in these records with the time scale generated by Berger and Loutre (1991) based on variations in the geometry of the Earth-sun orbital system. The resulting astronomically tuned time scale for the GRAPE record was used to recalibrate a section of the magnetic polarity time scale and was then applied to the extensive series of biostratigraphic datums determined during Leg 138 to refine the Neogene biostratigraphic time scale (see both chapters by Shackleton et al. in this volume). The result of this effort has been a set of internally consistent, high-resolution age models that provide an orbitally tuned absolute time scale for the past $6 \mathrm{~m} . \mathrm{y}$. For the period before $6 \mathrm{~m}$.y., the absolute time calibration is less secure, but it is better constrained than any previously offered.

Given the ability to examine the Leg 138 sites in the context of a robust high-resolution stratigraphy, we can begin to explore, with increased confidence, the nature of oceanographic and climatic changes in the eastern equatorial Pacific. As a starting point in our effort to synthesize the initial results of Leg 138, we use the remarkable stratigraphic framework produced by the Leg 138 scientists to explore the history of sedimentation in the region. First, we will present an overview of the spatial variability of the system, and then we will focus on several specific time intervals that exemplify the type of analyses that can be conducted with Leg 138 data.

\section{OVERVIEW OF TEMPORAL AND SPATIAL VARIABILITY OF THE EASTERN EQUATORIAL PACIFIC}

Farrell et al. (this volume) and Kemp (this volume) explore the spatial and temporal variability of a number of sedimentary components (composition, flux, and nannofossil preservation) of the Leg 138 region and put together a generalized evolution of sedimentation in the eastern equatorial Pacific. They have divided the temporal record into six intervals of distinctive sedimentary character:

1. 13-11.2 Ma: An interval characterized by moderately high carbonate concentrations and mass accumulation rates. The longer records at Sites $844-846$ indicate that these levels probably were present as far back as $18 \mathrm{Ma}$. Carbonate concentrations and fluxes were much higher than opal concentrations and fluxes during this interval, despite the fact that near-monospecific laminated diatom ooze (LDO) beds (see Kemp et al., this volume, and below) occur occasionally throughout this time period.

2. 11.2-9.8 Ma: Carbonate concentrations and fluxes decline at all sites, but opal concentrations and fluxes increase. LDO beds are prevalent during this time. Spatial gradients are dominated by the equator, though Sites 844 and 845 show relatively high carbonate accumulation rates.

3. 9.8-9 Ma: During this period, the eastern sites $(844,845$, and 846) had an almost complete loss of carbonate, whereas the western sites show a more subtle decline in carbonate. A relatively steep spatial gradient of carbonate accumulation is apparent, as equatorial sites maintain carbonate, but off-equatorial sites drop to near-zero accumulation rates. Diatoms appear to have been replaced by radiolarians as the major siliceous component at this time, and there is evidence for the accumulation of oxide-rich sediments. Nannofossil 
Table 1. Parameters used to backtrack Leg 138 sites to paleopositions.

\begin{tabular}{|c|c|c|c|c|}
\hline \multirow[b]{2}{*}{ Site numbers } & \multicolumn{2}{|c|}{ Pole } & \multirow{2}{*}{$\begin{array}{l}\text { Rotation rate } \\
\text { (degrees/Ma) }\end{array}$} & \multirow{2}{*}{$\begin{array}{c}\text { Time applicable } \\
\text { (Ma) }\end{array}$} \\
\hline & Latitude & Longitude & & \\
\hline \multicolumn{5}{|l|}{84} \\
\hline \multicolumn{5}{|l|}{495} \\
\hline \multirow{2}{*}{\multicolumn{5}{|c|}{$\begin{array}{l}503 \\
844\end{array}$}} \\
\hline & & & & \\
\hline \multirow[t]{2}{*}{845} & $16.8^{\circ} \mathrm{N}$ & $115.9^{\circ} \mathrm{W}$ & -1.336 & 0 to 5 \\
\hline & $19.1^{\circ} \mathrm{N}$ & $108.5^{\circ} \mathrm{W}$ & -2.052 & 5 to 19 \\
\hline \multicolumn{5}{|l|}{677} \\
\hline \multicolumn{5}{|l|}{846} \\
\hline & $41.9^{\circ} \mathrm{N}$ & $99.0^{\circ} \mathrm{W}$ & -0.47 & 0 to 5 \\
\hline & $40.1^{\circ} \mathrm{N}$ & $93.3^{\circ} \mathrm{W}$ & -0.916 & 5 to 19 \\
\hline \multicolumn{5}{|l|}{848} \\
\hline \multicolumn{5}{|l|}{849} \\
\hline \multirow{2}{*}{\multicolumn{5}{|c|}{$\begin{array}{l}850 \\
851\end{array}$}} \\
\hline & & & & \\
\hline \multicolumn{5}{|l|}{852} \\
\hline \multicolumn{5}{|l|}{853} \\
\hline \multirow[t]{2}{*}{854} & $61.6^{\circ} \mathrm{N}$ & $82.5^{\circ} \mathrm{W}$ & 0.97 & 0 to 5 \\
\hline & $70.3^{\circ} \mathrm{N}$ & $70.3^{\circ} \mathrm{W}$ & 0.73 & 5 to 11 \\
\hline
\end{tabular}

preservation is extremely poor during this interval, implying dissolution as the key agent in the loss of carbonate (see discussion below).

4. 9-6.6 Ma: A recovery in carbonate sedimentation occurs throughout the region, although it is more prevalent in the west than in the east. A less dramatic decrease in carbonate is noted at about 7.8 $\mathrm{Ma}$, followed by a rapid increase in carbonate sedimentation at all sites except the two northeasternmost sites ( 844 and 845 ), which have moved out of the equatorial divergence zone and remain relatively free of carbonate to the present day. Biogenic accumulation is concentrated around the equator, with some evidence of steepening spatial gradients in carbonate accumulation in both the east-west and north-south directions.

5. 6.6-4.5 Ma: During this period, all sites (with the exception of the northeastern Sites 844 and 845) experienced an extremely large increase in biogenic accumulation rates. Spatially, the pattern of sedimentation is somewhat similar to earlier patterns, but a clear expansion of the equatorial high-productivity zone is evident from the large increase in carbonate accumulation at the off-equator sites relative to the equatorial sites. Although accumulation rates were extremely high during this interval, they also were highly variable. This large increase in biogenic accumulation appears to be global in extent (see discussion below).

6. 4.5-0 Ma: Sedimentation rates along the western transect became moderate and remained relatively stable to the present (relative to the earlier Neogene), with a spatial concentration of carbonate accumulation around the equator. There is, however, a noticeable reduction in carbonate off the equator during the Cahiti-Mammoth interval (3.88-3.18 Ma) and a major shift in the locus of opal sedimentation from the western sites to the Galapagos region at about 3 $\mathrm{Ma}$. The diatom content of the sediment increased during the early Pleistocene, with a dominance of Thalassiothrix longissima but without the preservation of diatom mats. Terrigenous sediments are concentrated nearest the continental margin.

\section{LAMINATED DIATOM OOZES}

An intriguing result of Leg 138 was the recognition, within the preserved record, of intervals of near-monospecific assemblages of the pennate diatom, $T$. longissima, which are interpreted to be the depositional product of diatom mats (Kemp and Baldauf, 1993). In some time intervals, these very rapidly deposited, surface-derived laminated diatom oozes (LDO) are the primary source of carbonatesilica variability. Although exceptions do exist, almost all of the LDO intervals were deposited between $0^{\circ}$ and $2^{\circ} \mathrm{S}$. Temporally, the deposits are found intermittently between 15 and $4.4 \mathrm{Ma}$, with concentrations at about $15,13-12,11,10-9.5,6.3-6.1$, and $4.4 \mathrm{Ma}$; no lami- nated diatom oozes were observed in sediments younger than $4.4 \mathrm{Ma}$ (Kemp et al., this volume). The cessation of the preservation of LDO beds in the sediments of the eastern equatorial Pacific appears coincident with the final stages of the closing of the Isthmus of Panama (Keigwin, 1982a, 1982b) and with a shift in the locus of biogenous silica accumulation from the western sites of Leg 138 to the eastern ones (Farrell et al., this volume). The coincidence of these events supports the suggestion that mat formation is related to the formation of sharp east-west fronts (see below) and that the emergence of the Isthmus of Panama had a direct impact on the distribution of oceanographic gradients in the eastern equatorial Pacific (see Pisias and Moore, this volume).

By analogy to recent findings of Rhizosolenia mats in the eastern equatorial Pacific by JGOFS workers (Barber, 1992), Kemp et al. (this volume) propose that the LDO deposits represent the fallout of large "mat-forming events" that can occur when a strong east-west frontal zone is developed (e.g., in response to a La Niña event). This phenomenon can occur over periods of years (resulting in millimeterto centimeter-scale laminations), whereas decimeter-scale interbedding between LDO and nannofossil ooze may represent larger scale changes in circulation on time scales of hundreds to thousands of years. No evidence of reduced oxygenation of bottom waters has been found to be associated with the deposition of the LDO intervals. Instead, Kemp et al. (this volume) call upon the rapid deposition and extremely high tensile strength of the mats (making them virtually impenetrable to burrowers) to account for their preservation as laminated deposits, a result that may have important implications for the origin of other laminated sequences.

In some cases, individual LDO intervals can be correlated among sites over great distances. In a number of instances (in particular, 6.7-6.5 Ma, 6.1-5.9 Ma, and 4.8-4.5 Ma), regionally traceable seismic reflectors were found to correlate with the LDO intervals, implying the potential to map the lateral extent of these events seismically. Intriguingly, in several cases, the reflectors associated with distinct LDO intervals at some sites can be traced to sites where T. longissima is present in burrow fills but not as discrete mats. This implies that, despite the incomplete preservation of LDO mats, the sediment that accumulates over the entire region at that time is distinct enough from the material above and below it to generate a seismic reflection (Bloomer et al., this volume).

It is particularly intriguing to note that two of the seismic reflectors associated with the presence of $T$. longissima mats in the eastern equatorial Pacific (4.8-4.5 and 6.1-5.9 Ma) appear to be synchronous (to the best of our ability to reconcile differing stratigraphic bases), with regionally traceable seismic reflectors in the central equatorial Pacific that have been tentatively associated with decreases in carbonate content resulting from dissolution (Mayer et al., 1986; Bloomer et al., this volume). Although it is possible that the carbonate contrasts causing the central equatorial Pacific reflectors are also the result of increases in productivity, it is also possible this apparent contradiction results from the response of the CCD to the regionally restricted but intense productivity events that may be responsible for the $T$. longissima mats. An increased flux of organic matter that is localized in the eastern equatorial Pacific would result in the massive outpouring of opal beneath the locus of mat production (probably associated with the position of a front; see Kemp et al., this volume) and, thus, extremely low carbonate contents due to dilution by silica. This is clearly a mechanism to make a reflector. Outside the locus of enhanced opal deposition, steep gradients in the CCD (see Farrell et al., this volume), combined with a reduced flux of carbonate, would lead to enhanced dissolution of carbonate, which would also create a mechanism for reflector formation. Thus, we may have synchronous reflectors that are everywhere associated with low-carbonate content in the eastern equatorial Pacific. This low-carbonate content is a function of dilution, whereas in the deeper central equatorial Pacific (and off the equator), these low-carbonate intervals are associated with enhanced dissolution. 
We now leap from the broad-based approach more typical of past ocean drilling legs to focus on several intervals and approaches that exemplify the potential of Leg 138 data. As we do so, we move forward in time, calling upon the increasingly high- resolution record to present an increasingly more detailed picture of the temporal and spatial variability of the eastern equatorial Pacific.

\section{MIDDLE/LATE MIOCENE CARBONATE TRANSITION}

A major change in the nature of carbonate deposition in the eastern equatorial Pacific is recorded in the Leg 138 sedimentary records. Lyle et al. (this volume) and Farrell et al. (this volume) refer to this change as "the carbonate crash." As they demonstrate in their reconstructions of carbonate concentrations and mass accumulation rates (MAR), it is manifested by a very large decline in $\% \mathrm{CaCO}_{3}$ and a large decrease in carbonate mass accumulation rate, which is centered near the middle/late Miocene boundary ( $9.5 \mathrm{Ma})$. Spatially, carbonate sedimentation switched rapidly from a regime in which carbonate accumulation was evenly distributed throughout the eastern equatorial Pacific to one in which carbonate deposition virtually ceased at all of the Leg 138 sites except two equatorial sites ( 850 and 851 ) in the westernmost of the Leg 138 transects (Lyle et al., this volume, fig. 9; Farrell et al., this volume, figs. 16-23).

Farrell et al. (this volume) present a detailed chronology of the "carbonate crash," demonstrating that it appears to have begun in the Guatemala Basin between 12.5 and 12 Ma. By 11.2 Ma, all Leg 138 sites show the effects of reduced carbonate sedimentation (though it is still most pronounced in the Guatemala Basin), followed by fluctuations between times of enhanced opal productivity and enhanced dissolution (as indicated by poor nannofossil preservations) that culminated in the most intense reduction in carbonate accumulation at 9.5 Ma. At the peak of the "crash," the CCD shoaled by almost 1000 $\mathrm{m}$ in much of the eastern equatorial Pacific (Lyle et al., this volume); and, as mentioned above, the deposition of carbonate virtually ceased at all Leg 138 sites with the exception of the equatorial Sites 850 and 851 , which maintained carbonate MARs above $0.2 \mathrm{~g} / \mathrm{cm}^{2}$.

Between about 9.4 and $7.5 \mathrm{Ma}$, a general resumption of carbonate sedimentation occurred in the region, with the exception of the Guatemala and Peru basins, where the CCD remained between about 3400 and 3600 (and has remained there ever since), and where carbonate is accumulating today only on shallow ridge flanks (Lyle et al., this volume). Superimposed on this trend of increasing carbonate accumulation are several brief intervals of reduced carbonate deposition, much like the period leading up to the carbonate "crash." This transitional period led into the productivity-dominated late Miocene early Pliocene sedimentation rate maxima discussed below.

The decline in carbonate accumulation that dominates the eastern equatorial Pacific sedimentary record near the middle/late Miocene boundary is also seen in regions far beyond the eastern equatorial Pacific including the Atlantic (Berger, 1972). Theyer et al. (1985) and Mayer et al. $(1985,1986)$ correlated a middle/late Miocene carbonate low in the central equatorial with the "Mid-Epoch-10" carbonate event described by Vincent (1981) in both the Panama Basin and Hess Rise and with a Pacific-wide hiatus (or a time of reduced sedimentation, such as during NH4) described by Barron et al. (1985). This carbonate low is expressed as a seismic reflector that can be traced over thousands of kilometers across the central equatorial Pacific (Mayer et al., 1985, 1986). Mosher et al. (1993) identified a reflector in the western equatorial Pacific that was tentatively correlated with this central equatorial reflector, and Bloomer et al. (this volume) were able to link this central equatorial Pacific reflector with a similar reflector in the eastern equatorial Pacific, which they correlated with the 9.5-Ma "carbonate crash."

Farrell et al. (this volume) further explore the regional extent of the "carbonate crash" by rationalizing the age models and correlating the carbonate records (converted to mass accumulation rate) from a num- ber of central equatorial Pacific sites (RC12-65, RC12-66, DSDP Site 574) with those from Leg 138. During the period of the "carbonate crash," they found a close correspondence between the behaviors of carbonate accumulation in the central and eastern equatorial Pacific.

Not only was the middle/late Miocene carbonate decline far ranging in its effects, it also represents a major change in the nature of carbonate sedimentation in the eastern equatorial Pacific. Before the onset of this event, most equatorial Pacific sites show relatively consistent (high) values of both $\% \mathrm{CaCO}_{3}$ and carbonate MAR (Mayer, Theyer, et al., 1985; Farrell et al., this volume). In the eastern equatorial Pacific, the major changes in carbonate content before the "crash" appear to be related to the outpouring of silica in the form of laminated diatom mats. After the "crash," both carbonate content and MAR in the eastern equatorial Pacific show large-amplitude variations that are the result of a complex interaction between surface- and deep-water processes, but which appear to be dominated by the surface-water processes (Hagelberg et al., this volume; Pisias and Moore, this volume). As discussed below, the "carbonate crash" appears to be one of the few periods of time when eastern equatorial sedimentation was unequivocally dominated by deep-water processes.

Understanding variations in the carbonate record in terms of the relative contributions of dissolution and productivity is one of the more difficult challenges facing the student of equatorial paleoceanography. Nonetheless, Lyle et al. (this volume) and Farrell et al. (this volume) present cogent arguments for attributing the "carbonate crash" to enhanced dissolution associated with changes in bottomwater characteristics, rather than with changes in productivity. Although dissolution is difficult to quantify, a rudimentary nannofossil preservation index was constructed for the Leg 138 sites by Raffi and Flores (this volume) and was analyzed with respect to the carbonate record by Farrell et al. (this volume). Despite the poor resolution of the preservation index, only two time intervals clearly demonstrate poor nannofossil preservation and low nannofossil abundance, with the most pronounced dissolution occurring during the period of the "carbonate crash."

The association of the "carbonate crash" with enhanced dissolution does not, on its own, distinguish between surface- and deep-water processes for, as Emerson and Bender (1981) and Archer (1991a, 1991b) have demonstrated, under the proper conditions, increases in productivity can lead to enhanced dissolution through acids produced by the degradation of organic carbon. As Lyle et al. (this volume) demonstrate, however, a productivity increase of a factor of 8 (and an increase in $\mathrm{C}_{\text {org }}$ of 1 to 2 orders of magnitude) would be required to produce the measured change in the CCD (based on the modern relationship between the $\mathrm{CCD}$ and productivity). Leg 138 shipboard measurements of $\mathrm{C}_{\text {org }}$ do not exhibit such an increase, but rather a decrease in organic carbon at all sites except Site 846 (Mayer, Pisias, Janecek, et al., 1992; Lyle et al., this volume) during the period of the "carbonate crash." As further evidence for the absence of enhanced productivity, Farrell et al. (this volume) point out the anomalous lack of covariance between carbonate and opal MARs during the "carbonate crash" and the general lack of change in opal MAR from the levels preceding the "crash."

Given the rapid and wide-ranging decrease in carbonate accumulation that appears to be related to enhanced dissolution and is not associated with a major productivity increase, Lyle et al. (this volume) and Farrell et al. (this volume) explore various mechanisms that might account for the "crash." Noting the apparent correlation of the middle/late Miocene carbonate decrease and a global drop in sea level (Barron et al., 1985; Haq et al., 1987), Lyle et al. (this volume) dismiss sea-level change as a potential cause because Peterson et al. (1992) showed that globally, the middle/late Miocene sea-level drop is associated with a deepening of the $\mathrm{CCD}$ and enhanced carbonate preservation, a relationship supported by Berger's (1970) model of basinshelf fractionation. Instead, they call upon a rapid change in the chemistry of the deep waters of the eastern Pacific (decrease in $\left[\mathrm{CO}_{3}\right]^{-2}$ ) and suggest two possible mechanisms-(1) the constriction 
of the Panama Gateway or (2) the onset of North Atlantic Deep Water (NADW) - as the ultimate causative mechanisms.

When evaluating these two mechanisms, Lyle et al. (this volume) tend to favor the Panama Gateway mechanism, citing that the initiation of NADW should make global bottom waters less corrosive to carbonates, as NADW, with its high $\left[\mathrm{CO}_{3}\right]^{-2}$, replaces the more corrosive Antarctic Bottom Water. Although this may indeed be the ramification of the onset of NADW, Berger (1970) and Mayer et al. (1985) suggested that the initiation and increase of NADW flow would tend to suppress the upwelling of AABW in the south Atlantic and increase the flow of more corrosive $\mathrm{AABW}$ into the Pacific (basin-basin fractionation). Berger et al. (1993) elaborated on these arguments but tried to explain the chemical history of the western equatorial Pacific, calling NADW "the master modulator." Farrell et al. (this volume), however, take a detailed look at the history of NADW (converted to the Leg 138 time scale) and fail to find synchroneity between NADW behavior (as outlined by Bohrmann et al., 1990, and Wright et al., 1991, 1992) and the history of sedimentation in the eastern equatorial Pacific, though the ability to make such detailed temporal comparisons must be questioned.

Lyle et al. (this volume) favor the closing of the Panama Gateway (and the resulting decrease in the flow of high $\left.\mathrm{CO}_{3}\right]^{-2}$ water from the Atlantic to the Pacific) as the mechanism responsible for the middle/ late Miocene "carbonate crash." In supporting this mechanism, Lyle et al. (this volume) cite the spatial pattern of the crash. They note that the eastern basins of the equatorial Pacific were most strongly affected (where the CCD never again deepened) and that if the "crash" were the result of NADW-induced changes in deep-water circulation, other parts of the Pacific should have been the most strongly affected. They also estimate that a restriction of flow from the Atlantic to the Pacific of only about $2 \mathrm{~Sv}$ is needed to produce the changes in carbonate preservation measured in the eastern equatorial Pacific. Farrell et al. (this volume) add support to Lyle et al.'s (this volume) suggestion by pointing out the apparent synchroneity between the carbonate history of the eastern equatorial Pacific and changes in the sill depth of the nascent Isthmus of Panama and the results of ocean models (MeierReimer et al., 1990; Mikolajewicz et al., 1993) that predict that deep water should have flowed from the Caribbean to the Pacific before the uplift of the isthmus.

The arguments presented above clearly indicate that the time around the middle/late Miocene boundary was one of major change for the eastern equatorial Pacific and, perhaps, for most of the ocean basins. Unlike many of the carbonate variations that precede and postdate it, the middle/late Miocene "carbonate crash" of the equatorial Pacific represents a major dissolution event. The changes in bottomwater chemistry associated with this event (or series of events) appear to be related to the early phases of the closing of the Panama Gateway. The role of NADW initiation and intensification in controlling carbonate accumulation in the eastern equatorial Pacific is still not resolved; however, as pointed out by Farrell et al. (this volume), the ocean modeling of Maier-Reimer et al. (1990) and Mikolajewicz et al. (1993) demonstrates that the closing of the Panama Gateway may also have had a direct influence on NADW production and, thus, the effects of both changes in Panama Gateway sill depth and the production of NADW may be manifested in the history of eastern equatorial Pacific sedimentation.

\section{LATE MIOCENE-EARLY PLIOCENE SEDIMENTATION RATE MAXIMA}

As discussed above, one of the most striking phenomenon of the late Miocene and early Pliocene is the extremely high biogenic sediment accumulation rates at nearly all Leg 138 sites. In Figure 5, we show the sedimentation rates (in meters per million years) for all sites (except Guatemala Basin Sites 844 and 845) drilled during ODP Leg 115 and DSDP Leg 85. All sites, even sites from the western equatorial Pacific and equatorial Indian Ocean, demonstrate high accumula- tion rates between 3.5 and $6.5 \mathrm{Ma}$ (Fig. 5). The sites from Leg 138, in which a high-resolution chronostratigraphy was based on the hypothesis of orbital tuning (Shackleton et al., this volume), show that this maximum starts at $6.5 \mathrm{Ma}$, with sedimentation rates returning to pre- $6.5 \mathrm{Ma}$ levels by $3.5 \mathrm{Ma}$ (Fig. 5 ). During this maximum, sedimentation rates at the equator reach levels of nearly $100 \mathrm{~m} / \mathrm{m}$.y. and are nearly five times higher than sedimentation rates of the late Pliocene and Pleistocene. Integrated over the Leg $138110^{\circ} \mathrm{W}$ transect is an approximately threefold increase in the total amount of sediment accumulation between the sedimentation rate maximum from 6.0 to 6.4 Ma, as compared to the 0 - to 0.47 -Ma intervals (Fig. 5). In the western Pacific, sedimentation rates change by a factor of 3 (Berger et al., 1993), indicating that this was at least an equatorial-wide change in sediment accumulation.

The high-resolution paleoceanographic studies from Leg 138 provide some insights into how surface oceanographic processes changed at the end of this sedimentation event. Eolian grain-size data from the late Miocene and early Pliocene suggest that the ITCZ was farther north than its present position and moved south of Site $853\left(7^{\circ} \mathrm{N}\right)$ between 4 and $5 \mathrm{Ma}$ (Hovan, this volume). The analysis of variation in carbonate deposition during the past 6 m.y. shows that the modes of variability within the equatorial Pacific were more zonal during the early Pliocene than in the later Pliocene and Pleistocene (Hagelberg et al., this volume).

Isotopic gradients, as determined by analyses of bulk carbonates, indicate a stronger north-south gradient across the equator before about $5 \mathrm{Ma}$. The gradient suggests a colder equatorial zone during the interval of high sedimentation consistent with what might be expected if equatorial circulation were intensified and more zonal (Shackleton et al., this volume). Thus, the available data suggest that during the maximum sedimentation rate intervals, equatorial circulation was more zonally aligned (i.e., contour patterns were much more parallel to the equator and the influence of the "Peru Current" is reduced) and more focused around the equator. This is further supported by the north-south pattern in sedimentation rates during the time of maximum accumulation (Fig. 4). A similar conclusion was reached by Pisias and Prell (1985) on the basis of results from Leg 85 in the central equatorial Pacific combined with the synthesis of van Andel et al. (1975). Thus, we feel that it is reasonable to suggest that during the time of maximum accumulation, the circulation of the equatorial Pacific was much more symmetrical and focused at the equator that at present.

Was this change in surface circulation associated with increased productivity, or were the changes in calcium carbonate and biogenic silica accumulation a result of changing sediment preservation? To examine these questions, we first consider the present observed flux of calcium carbonate and biogenic silica in the equatorial Pacific. The maximum annual flux of calcium carbonate and opaline silica measured by sediment traps from the equatorial Pacific range from 2.3 and $0.7 \mathrm{~g} / \mathrm{cm}^{2} / \mathrm{k}$.y. at traps deployed in 1991 at $140^{\circ} \mathrm{W}$ (JGOFS transect; Dymond, Collier, and Suess, written comm.) to an annual flux of 3.0 and $1.5 \mathrm{gm} / \mathrm{cm}^{2} / \mathrm{k} . \mathrm{y}$. measured at traps deployed during 1983 and 1984 at $139^{\circ} \mathrm{W}$ (Dymond and Collier, 1988). The JGOFS deployment spanned the weak El Niño event of 1991, whereas the fluxes measured by Dymond and Collier (1988) are from a deployment the year after the major 1983 El Niño event. Based on the 2-yr deployment of Dymond and Collier (1988), we assume that the 1984 data are a reasonable representation of non-El Niño sediment fluxes.

Unfortunately, we do not have sediment trap data from the area of the Leg 138 sites and, thus, we do not have a direct estimate of the gradients in particle fluxes along the equator. To evaluate possible primary fluxes at the Leg 138 transect, we took two approaches, one based on sediment accumulation gradients and the other based on gradients of primary productivity along the equator.

Sediment mass accumulation rates for calcium carbonate at equatorial sites at $95^{\circ}, 113^{\circ}, 139^{\circ}$, and $140^{\circ} \mathrm{W}$ show few differences along the equator (Murray et al., this volume), whereas the accumulation of 
biogenic opal increases by a factor of 2 between $140^{\circ}$ and $110^{\circ} \mathrm{W}$ (Farrell et al. and Murray et al., both in this volume). If we take the observed pattern of opal accumulation to suggest an increase in the flux of both carbonate and opal between $140^{\circ}$ and $110^{\circ} \mathrm{W}$, then the lack of an accumulation rate gradient of calcium carbonate requires an east-west gradient in the preservation of calcium carbonate that exactly balances the increased flux of calcium carbonate. This would suggest better preservation of calcareous fossils to the west, which is not the general case. If we only allow opal flux to increase along the equator to account for the sediment accumulation patterns, then we require the rain ratio of carbonate and opal to decrease by a factor of 2 along this productivity gradient. Although possible, this inference is not consistent with changes in the ratio of carbonate and opal observed in sediment traps along a comparable productivity gradient. For the JGOFS $110^{\circ} \mathrm{W}$ transect, the ratio of carbonate to opal changes from about 2.5 to 3 over a fourfold change in total flux, with the highest ratios found at the highest flux equatorial site (Dymond, Collier, and Suess, written comm.). Finally, if there is little gradient in the particle flux of opal along the equator between the sediment trap sites and the Leg 138 transects, then this would require better opal preservation at $110^{\circ} \mathrm{W}$ vs. $140^{\circ} \mathrm{W}$. Qualitatively, the radiolarian fauna tend to be better preserved in the eastern Pacific as compared to the central equatorial Pacific, which supports this inference.

The compilation of surface productivity estimates by Berger et al. (1987) shows that surface primary productivity changes between $110^{\circ}$ and $140^{\circ} \mathrm{W}$ by a factor of 2 to 3 . As summarized by Bishop (1989), several researchers (Suess, 1980; Betzer et al., 1984; Berger et al., 1987; Pace et al., 1987) have empirically related primary productivity to particle flux. With the exception of Betzer et al. (1984), these relationships show a linear change in particle flux with changes in primary productivity. Thus, based on the increase by a factor of 2 to 3 in primary productivity between $110^{\circ}$ and $140^{\circ} \mathrm{W}$, we assume a similar increase in particle fluxes. We must also assume that the relationship between carbon flux and opal and carbonate fluxes also is constant. This assumption is supported by the very high correlation between organic carbon flux and the sum of carbonate and biogenic fluxes in a wide range of sediment trap deployments (Fischer, 1984) and the relatively constant carbonate to opal ratios seen in equatorial Pacific traps. Thus, although these two lines of evidence (sedimentation accumulation rate patterns and changes in surface primary productivity) are not conclusive, taken together we suggest that the factor of 2 increase in sediment flux at $110^{\circ} \mathrm{W}$ (as compared to $140^{\circ} \mathrm{W}$ ) would not be unreasonable.

Based on these assumptions, we would estimate the modern-day particle flux of carbonate and opal at the equator and $110^{\circ} \mathrm{W}$ to be about 6 and $3 \mathrm{~g} / \mathrm{cm}^{2} / \mathrm{k}$.y., respectively. Compared with recent sediment accumulation rates at Site 849 , this would suggest that about $30 \%$ of the calcium carbonate rain and about $7 \%$ of the opal rain is preserved in the sediments. During the time of maximum sediment accumulation at Site 849, carbonate and opal fluxes were 4.5 and 0.8 $\mathrm{g} / \mathrm{cm}^{2} / \mathrm{k}$.y. (Farrell et al., this volume), which would require preservation of $75 \%$ of the carbonate rain and more than $26 \%$ of the opal rain if surface production remained constant. Indicators of nannofossil dissolution do not support this inference. In general, dissolution was higher at Site 849 during the interval of high accumulation rates as compared to the lower sedimentation rate intervals before and after the event (Farrell et al., this volume). Thus, although our estimated modern particle flux could sustain the high sedimentation rates of the latest Miocene and early Pliocene, the evidence strongly suggests that the changes in oceanographic circulation pattern inferred from the Leg 138 data also were accompanied by higher production in the eastern equatorial Pacific.

It is tempting to speculate that the transition from the interval of high sedimentation rates, with the proposed changes in surface circulation, is related to the closing of the oceanic connection between the tropical Pacific and Atlantic. Unfortunately, modeling results do not provide evidence that the closing of the Panamanian Isthmus would

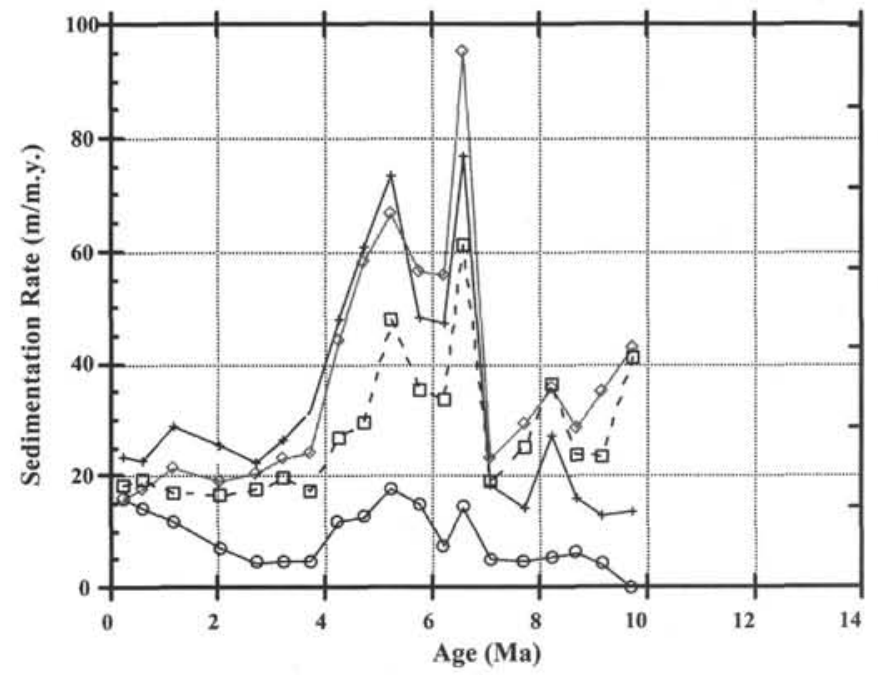

Figure 5. Sedimentation rate curves for the eastern equatorial Pacific. Site 848 $=$ open circles, Site $849=$ plus signs, Site $850=$ open diamonds, and Site 851 = open squares.

produce such a change in surface circulation (Maier-Reimer et al., 1990; Mikolajewicz et al., 1993). Indeed, the models predict little change in surface circulation associated with an open or closed isthmus. However, one important weakness of these models is that present-day atmospheric forcing is imposed on the model ocean. Thus, the effect of a more northerly position of the ITCZ is not accounted for in these model results.

Although it is tempting to invoke a closing of the Panamanian Seaway as an explanation for the reduction in sediment accumulation during the early Pliocene and associated changes in patterns of surface ocean circulation, this does not help explain the onset of the sediment accumulation rate maximum at $6.5 \mathrm{Ma}$. Unfortunately, the high-resolution studies produced to date from Leg 138 drill sites do not provide insights as to the potential oceanographic changes associated with the onset of the high sediment accumulation rate of the latest Miocene and early Pliocene.

To address the dilemma posed by the mid-Neogene accumulation rate maximum, we must also consider sediment accumulation on a more global basis. As shown in Figure 5, the accumulation rate maximum is not unique to the eastern equatorial Pacific. Maximum accumulation rates in carbonate sediments are seen in the western equatorial Pacific and in the equatorial Indian Ocean. Recent drilling results from Leg 145 show that, during the mid-Neogene, opal accumulation rates were much higher in the North Pacific than at present (Rea and Basov et al., 1991) and that maximum sedimentation rates are found in the South Atlantic. Clearly, this event is not unique to the eastern equatorial Pacific.

If this event is global and involves both increased biogenic silica and carbonate burial, then either the net flux of $\mathrm{Ca}$ and $\mathrm{Si}$ to the ocean must have increased during this time or an as yet-undefined oceanic sink must not have been active during the mid-Neogene. In the absence of evidence for another oceanic sink, we propose that during the mid-Neogene the chemical flux into the ocean was elevated above present-day levels. The evidence for enhanced oceanic productivity in the equatorial Pacific would be supported by increase fluxes of phosphorous (Filipelli and Delany, this volume) and other nutrients, along with the fluxes of $\mathrm{Ca}$ and $\mathrm{Si}$.

A similar hypothesis of enhanced dissolved flux to the ocean during the Neogene comes from studies of the evolution of the Indian Ocean Monsoon and its relationship to the uplift of Tibet and the Himalayas. The onset of the Indian Monsoon, based on marine and continental records, took place during the latest Miocene at about 6-7 
Ma (Molnar et al., 1993). It has been proposed that the uplift of the Himalayas and the Tibet Plateau was a major factor in the development of the monsoon circulation system. Modeling results using a general circulation model of the atmosphere support this hypothesis (Prell and Kutzbach, 1992). Associated with the uplift of this region is evidence for increased continental weathering and river flux to the ocean. Strontium and carbon isotopes from marine carbonates can be used to infer changes in river and carbon flux into the ocean, and the available data show that the mid-Neogene was a time of enhanced flux to the ocean (Raymo, 1994). Enhanced chemical weathering of the Himalayas during the mid-Neogene also is supported by clay mineralogy and isotopic analysis of terrigenous sediments from the northern Indian Ocean (France-Lanord et al., in press). These data show that mechanical erosion was a dominate process before about $6.8 \mathrm{Ma}$ and after about $0.8 \mathrm{Ma}$, as indicated by the coarser grained sediments and clay mineralogy indicative of reduced chemical weathering. During the interval from 6.8 to $0.8 \mathrm{Ma}$, however, finer grained sediments and abundances of smectite and kaolinite suggest stronger chemical weathering. Neodinium and strontium isotopes indicate a common source area for all of these sediments and, thus, support the hypothesis that chemical weathering in the Himalayas was more intense during the mid-Neogene.

Thus, we propose the following scenario for the mid-Neogene evolution of the eastern equatorial Pacific. The onset of the maximum accumulation rate was a response to the overall increased flux of $\mathrm{Ca}$ and $\mathrm{Si}$ and associated nutrients to the ocean that enhanced sediment accumulation, not only in the equatorial Pacific but throughout the world's oceans. This increased flux to the ocean is related to the increased chemical weathering associated with the evolution of the Himalayas and the Tibetan Plateau. Increased uplift of this region affected the eastern equatorial Pacific in two ways. As chemical weathering decreased and associated flux to the ocean decreased, net accumulation rates also decreased. Second, the increased elevation and enhancement of the Indian Monsoon system is also associated with larger scale changes in climate. The results using atmospheric general circulation models to examine the evolution of the Monsoon system to increased orographic effects also show that significant changes in surface winds have been found in other parts of the world. In the eastern equatorial Pacific model, surface winds from the northeast are enhanced with increased elevation of the Himalayas, as compared to model runs without mountains. The enhanced northeast flow associated with increased topography is consistent with the observed changes in eolian sediments in the eastern equatorial Pacific (Hovan, this volume). Although these models do not yet provide a detailed picture of changes in surface winds over the ocean, they do demonstrate that the effects of Himalayan uplift were not restricted to only the regions of the monsoons. This scenario does not require the uplift of Panama and the closure of the Atlantic-Pacific tropical connection, but changes in this region may also have played an important role in the observed surface oceanographic changes documented from Leg 138 studies.

\section{CLIMATE VARIABILITY DURING THE LATE NEOGENE}

One of the primary goals of Leg 138 was to obtain paleoceanographic records spanning the late Neogene to document Earth's climate response on time scales of a few thousands of years. The response of Earth's climate to solar insolation changes is clearly demonstrated for the late Pleistocene (Imbrie et al., 1992, 1993), and the evolution of this response over the last million years has been studied from standard piston cores (Pisias and Moore, 1981) and drill sites (e.g., Shackleton et al., 1990; Ruddiman et al., 1987). However, few high-resolution records are available that span more than a few million years.

A major success of Leg 138 was the documentation of complete recovery at sites where at least $6 \mathrm{~m}$.y. of continuous sediment records can be studied (Hagelberg et al., 1992, and this volume). These records provide an important opportunity to study climate response on time scales of a few thousands to a few tens of thousands of years over the late Neogene. At one site (846), we can assemble from the initial results of Leg 138, a complete 6-m.y.-long record of changes in the stable isotopic composition of the deep Pacific, as well as a record of changing carbonate accumulation (Fig. 6). Implications of the isotopic record are discussed by Shackleton et al. (this volume). Here, we present a time-series analysis of this record as well as the record of changing Northern Hemisphere solar insolation and changes in carbonate concentration at Site 846, as estimated from GRAPE bulk density.

To explore the evolving nature of variations in the carbonate system, global ice volume, and solar insolation, an evolutionary spectral calculation was made for this solar insolation time series, as well as for the Site 846 benthic oxygen isotope and carbonate records (derived from GRAPE; see Mayer, 1991, and Hagelberg et al., this volume), using the following parameters: All spectra were calculated over a 900,000-yr time interval, with a sampling interval of 5,000 yr. Spectra and cross-spectra were calculated using the lagged autocovariance strategy of Jenkins and Watts (1968). Fifty-one terms of the autocovariance were used for spectral calculations, which provided $10^{\circ}$ of freedom. An evolutionary spectral matrix was generated by offsetting each $900,000-y r$ interval by $10 \%$. Thus, spectra were calculated for the intervals $0-900 \mathrm{ka}, 90-990 \mathrm{ka}, 180-1080 \mathrm{ka}$, and so forth. The last spectral calculation is for the interval $4860-5760 \mathrm{ka}$. Spectral and cross-spectral calculations were made for solar insolation at $65^{\circ} \mathrm{N}$ vs. oxygen isotopes, insolation vs. carbonate, and oxygen isotopes vs. carbonate. Each cross-spectral calculation produces a two-dimensional array (the dimensions being time and frequency) of four variables: variance (for each time series), coherency between time series, and relative phase. These variables, therefore, are calculated at all specific frequencies and time intervals. To display the first three variables, we have chosen a three-dimensional relief presentation (Fig. 7). Time and frequency are represented by their $x-y$ positions, and the variance of a time series is shown in the third dimension as a topographic surface. On the topographic surface, the color red is used to illustrate where significant coherence (at the $80 \%$ confidence interval) is found between the two time series being analyzed. These results are shown in Figure 7. Note that the topography in Figures 7C and $7 \mathrm{D}$ are the same, with both representing the variance distribution vs. time and frequency of the oxygen isotopic record of Site 846. Likewise, the topography of Figures $7 \mathrm{E}$ and $7 \mathrm{~F}$ represent the variance distribution of carbonate. The coherence in both Figures 7D and 7F are the same, representing the coherence between the carbonate and oxygen isotope time series.

This analysis allows us to look at the long-term evolution in the response of the climate records from Site 846 and in the solar insolation and orbital records. Because of the $900,000-\mathrm{yr}$ interval used to calculate spectra, we can only look at the longer term evolution. Other time-series analysis techniques are required to look at the evolution of the climate system over much shorter time scales. We present these results to provide an overall view of late Neogene climate change.

First, we discuss the spectral evolution of solar insolation over the past $6 \mathrm{~m} . \mathrm{y}$. We use this insolation record (based on many previous studies that consider summer insolation at $65^{\circ} \mathrm{N}$ to be critical) for forcing late Pleistocene glacial interglacial cycles (e.g., Milankovitch, 1930; Broecker and von Donk, 1970; Hays et al., 1976; Imbrie and Imbrie, 1980). The spectra of solar insolation at $65^{\circ} \mathrm{N}$ is dominated by frequencies associated with the precession of the Earth's axis, the 23,000- and 19,000-yr periods. The tilt of the axis has a much smaller impact on summer radiation at this latitude. Over the past 6 m.y., the relative importance of the two frequencies of precession shows significant changes. The largest change is found in the contribution of the 19,000-yr frequency component. The amplitude of this component shows a regular, almost periodic, pattern to changes in its intensity. The amplitude of the 19,000-yr component has maxima at 1.3 and 4.2 

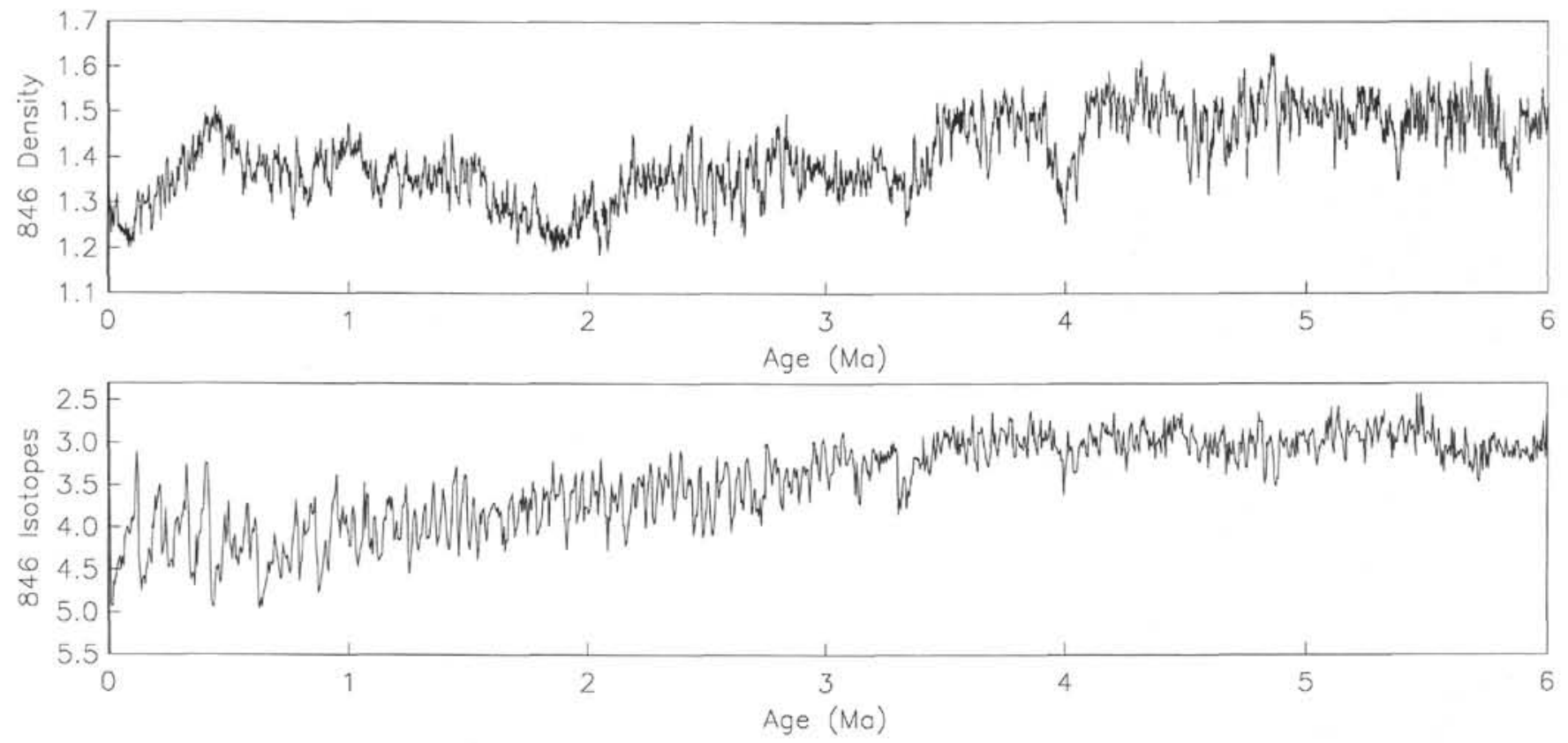

Figure 6. Isotopic and GRAPE time series from Site 846. Data are from Shackleton et al. (this volume) and Mix et al. (this volume).

$\mathrm{Ma}$ and minima at 2.8 and $5.2 \mathrm{Ma}$. At the 1.3-Ma maximum, the largest amount of variance in summer solar insolation at $65^{\circ} \mathrm{N}$ is found in the 19,000-yr period. This is true over the interval from about 0.5 to $1.75 \mathrm{Ma}$.

The changes in the amount of variance at the 23,000-yr period of precession and the 41,000-yr period of axial tilt show much reduced variations, as compared to the 19,000 -yr period. The changes in the 23,000-yr period are much smaller and occur at a higher frequency than the other two components of summer insolation (Fig. 7A). The changes in the 23,000-yr component reflect the amplitude modulation of the precession effect by orbital eccentricity, and thus the pattern reflects the 100,000 -yr period of eccentricity. Interestingly, the interaction of the orbital frequencies at the 19,000 -yr period of precession is reflected only in long period changes in the amplitude of this orbital component. However, as noted above, because of the $900,000-\mathrm{yr}$ interval used for spectral calculations, we are seeing a much reduced modulation effect of eccentricity on the 23,000 -yr period.

To examine the changes in the amount of variance in solar insolation related to tilt in more detail, we show the evolutionary spectra of axial tilt in Figure 7B. In the 41,000-yr tilt period, two intervals can be observed in which the amount of variance is reduced (from 3 to 3.5 $\mathrm{Ma}$ and from about 4.3 to $4.6 \mathrm{Ma}$ ).

Examination of the evolutionary spectra of the oxygen isotope record from Site 846 shows a complex pattern of response to the frequency distribution observed in the evolutionary spectra of insolation and in orbital tilt (Figs. 7A-7C). Let us consider the tilt frequency first. In the early part of the record, before $4.5 \mathrm{Ma}$, variance at 41,000 $\mathrm{yr}$ is relatively small, and we see no coherence with solar insolation (Fig. 7C). In addition, we see a relatively large change in the variance in the tilt frequency band between 6 and $4.5 \mathrm{Ma}$, which is not mirrored in the isotope record. From 0 to $4.5 \mathrm{Ma}$, the 41,000 -yr period in the isotopic record is coherent with insolation. At $4.5 \mathrm{Ma}$, where we see the first significant coherence between the tilt frequencies of insolation and the oxygen isotope record, there is an initial increase in the response of the isotope record to orbital forcing. This increase in response corresponds to an increase in the amount of variance in the forcing (Figs. 7B and 7C). Clearly, the sensitivity of the oceanic isotope system to orbital forcing is very small before $4.5 \mathrm{Ma}$, but the increased response at 4.5 Ma reflects either an increasing sensitivity of the climate system and/or the increased amount of forcing over this interval. The increased response at $4.5 \mathrm{Ma}$ is also coincident with a shift in the locus of opal production from the westernmost sites of Leg 138 to the eastern sites and a cessation in the preservation of LDO beds (Farrell et al. and Kemp, both in this volume). Thus, identifying the timing of specific climate events that might have contributed to an increased sensitivity of the climate system is complicated by the simultaneous increase in the amount of orbital forcing. For example, the processes related to increased climate sensitivity may have changed before $4.5 \mathrm{Ma}$ but until the amount of forcing increased to a sufficient level, the response did not appear until a later time.

Comparison between changes in the amount of variance in the tilt record and the climate system after about $4.5 \mathrm{Ma}$ suggests that changes in the response of the isotope record are simply related to changes in orbital forcing (Figs. 7B and 7C) with even the very recent (past few hundreds of thousands of years) increase in the amount of variance in the isotope record at $41,000-\mathrm{yr}$ periods, which is seen in the tilt spectra.

Overall, precessional frequencies of 19,000- and 23,000-yr periods contain a relatively small amount of variance in the isotope record over the past $6 \mathrm{~m} . \mathrm{y}$. Before about $3.1 \mathrm{Ma}$, we see little coherence between orbital forcing and the isotopic record. After about $3.1 \mathrm{Ma}$ and except for the interval $0.5-1.5 \mathrm{Ma}$, significant coherence between precession and isotopes is found (Fig. 7C). Unlike with the 41,000-yr frequency band, we do not see a simple relationship between the long-term changes in the amount of variance precessional bands of the isotope record and the solar insolation data.

As expected, we see no coherence between solar insolation and the isotope record at low frequencies. At very low frequencies, periods longer than $400,000 \mathrm{yr}$, there are two intervals where low-frequency variance is an important part of the isotope record, before about 4.6 $\mathrm{Ma}$ and after 3.2 Ma. Between 4.5 and 3.2 Ma, very little variance is seen at these low frequencies. The older interval (4.6 Ma) does not have variance at the $100,000-y r$ frequency of eccentricity, whereas in the interval Ma, the $100,000-\mathrm{yr}$ period is one of the dominant components in the data spectrum.

The evolutionary spectra for carbonate are shown in Figures 7E and $7 \mathrm{~F}$. In the carbonate spectra, the $41,000-\mathrm{yr}$ period is apparent throughout most of the record, with the largest contribution to the data variance between 5 and $6 \mathrm{Ma}$ and between 1.9 and $3.1 \mathrm{Ma}$. The carbonate time series are coherent with orbital forcing over the inter- 


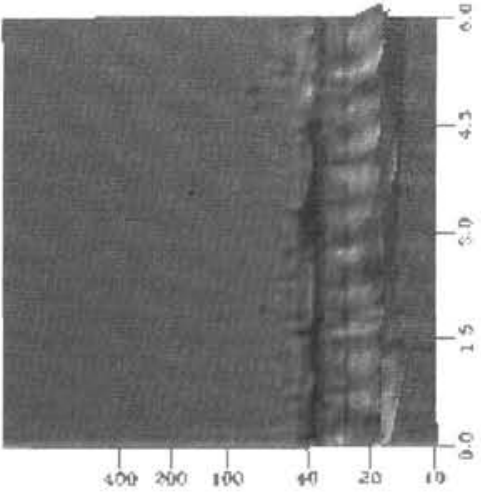

Period (Years)

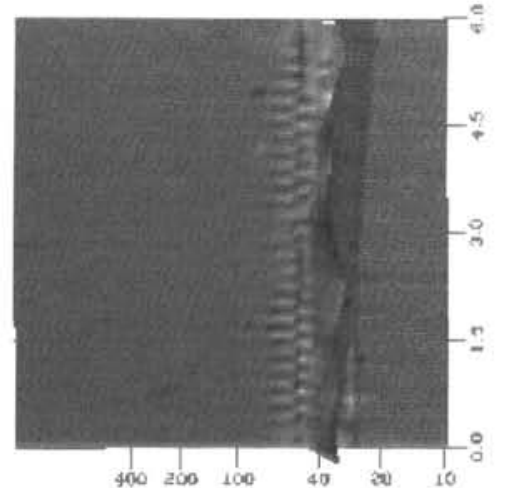

Period (Years)

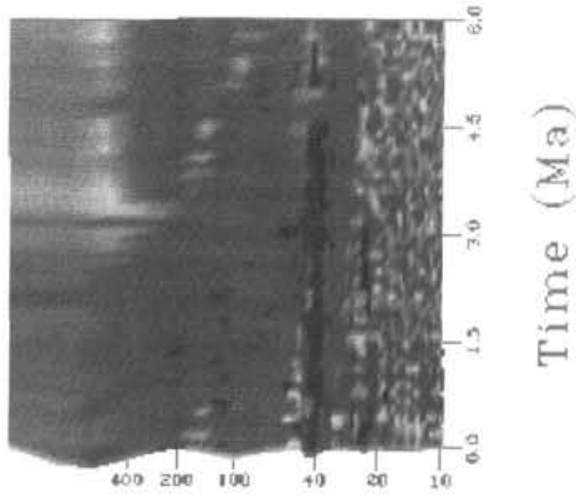

D ISOTOPES/GRAPE

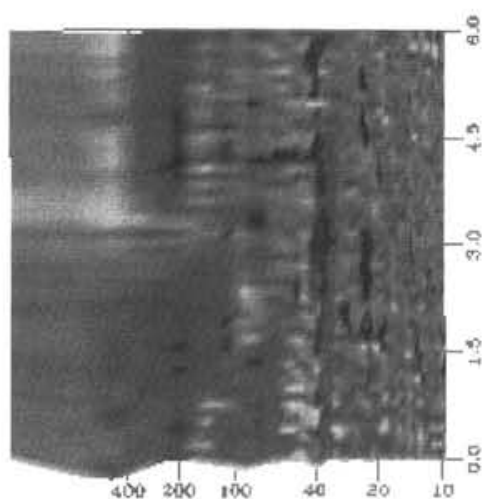

Period (Years)
E

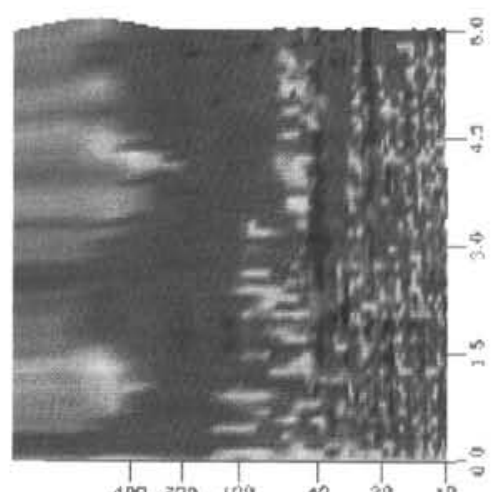

$\lim _{400}>000$

Period (Years)
Period (Years)

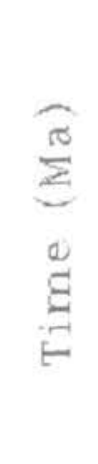

Figure 7. Evolutionary spectra for isotope and GRAPE time series from Site 846. All spectra were calculated for a 900,000-yr-long time series. Frequency scale is labeled in thousands of years. Time axes give time at the end of each 900,000 -yr interval used for spectral calculation. Thus, the spectra at $0 \mathrm{Ma}$ is for the time interval from 0 to $900 \mathrm{ka}$, and the spectra at 1 $\mathrm{Ma}$ is for the interval from 1000 to $1900 \mathrm{ka}$. Relief represents the variance that each frequency contributes to the time series, with non-red colors coded to the amplitude of the variance peak. Red indicates frequencies and time, where appropriate data pairs show significant coherence. A. Spectral calculations for summer solar insolation at $65^{\circ} \mathrm{N}$. Red shows coherence between orbital forcing and the $\delta^{18} \mathrm{O}$ record. B. Spectral calculations for orbital tilt. C. Spectral calculations showing the variance spectra for the $\delta^{18} \mathrm{O}$ record, with significant coherency between $\delta^{18} \mathrm{O}$ and insolation shown in red. D. Variance spectra for $\delta^{18} \mathrm{O}$ and coherency between the isotope record and GRAPE. E. GRAPE density spectra and coherency with solar insolation. F. GRAPE density spectra and coherency with $\delta^{18} \mathrm{O}$. QUICKTIME movies of each frame in color can be found on the CD-ROM (back pocket). 
val from about 1.9 to $6 \mathrm{Ma}$ (Fig. 7E), but they are only coherent with isotopes from 1.5 to $6 \mathrm{Ma}$ (Fig. $7 \mathrm{~F}$ ). In the older part of the record, the changes in variance in the carbonate system at the $41,000-y r$ period, unlike the isotope record, very much follow the orbital tilt forcing. The decreasing variance in the 41,000-yr frequency band between 6 and $5 \mathrm{Ma}$, with the subsequent increase at $4.5 \mathrm{Ma}$ and the large peak in variance between 1.9 and $3.1 \mathrm{Ma}$, are also seen in the tilt evolutionary spectra (Figs. 7B and 7E). However, because the isotope record shows sensitivity to orbital forcing throughout the younger part of this time interval, after the decrease in response in the carbonate system at $1.9 \mathrm{Ma}$, the carbonate variations in the equatorial Pacific show little direct response to the 41,000-yr component of insolation changes.

At the precession frequencies, the carbonate signal, unlike the isotope record, is coherent with insolation over most of the record. Carbonate variations at Site 846 are coherent with the isotope record in the precession band before 1.5 Ma. Thus, before the Pleistocene, there appears to be more coupling between the isotopic record and carbonate variations at Site 846 than during the last $1.5 \mathrm{~m} . \mathrm{y}$. The reduced coupling between these two records appears at the same time that long period responses in the isotope record become much more important, suggesting that the different processes that control isotopic variations have become more dominant and that these processes are less coupled to carbonate variations in the eastern equatorial Pacific.

At low frequencies, we see a similar behavior in the isotope and carbonate records before $3.5 \mathrm{Ma}$. Both have relatively strong contributions in variance at periods greater than 400,000 -yr, but these frequencies are not coherent (Figs. 7D and 7F). In the younger part of the records, the low-frequency components of the carbonate and isotope records differ. We see a large amount of variance concentrated at the long periods of the carbonate record centered at about $1.5 \mathrm{Ma}$, but the amount of variance decreases after this time in the carbonate record (Fig. 7F), whereas the amount of variance in low frequencies increases in the isotope record from about 1.5 Ma (Fig. 7D).

In summary, examination of the evolutionary spectra of the oxygen isotope and carbonate records shows that modulation in precession forcing is not found in these climate variables. Over the 900,000 intervals in which the spectra and cross-spectra are calculated, there is significant coherence between insolation and these climate records for most of the late Neogene (Figs. 7B and 7E); however, we do not see the same long-term evolution in the precession band of this forcing function reflected in the response of the climate system. In the $41,000-\mathrm{yr}$ frequency band, we see a much more linear response, at least over some intervals, between the isotope and carbonate records from the equatorial Pacific and solar forcing. However, because the carbonate system seems much more tightly coupled to insolation changes before about $1.9 \mathrm{Ma}$, the isotope record does not show sensitivity to orbital tilt until at least $4.5 \mathrm{Ma}$.

In the carbonate and isotope records, only one time stands out when all frequencies within a climate record respond in a similar manner. This occurs during the last half million years, when we see a marked increase in the response of the isotopic record at the orbital frequencies, including the 100,000 -yr eccentricity frequency as well as very long periods. In the carbonate record, no obvious links occur between frequencies. However, an important feature of the carbonate and isotope spectra is the maximum in 41,000 -yr period variance at 2.7 Ma. The decrease in variance associated with tilt frequency in the carbonate time series is also the time when low-frequency components become much more important. More detailed time-series analysis will be required to determine if nonlinear interactions among these frequencies are present.

\section{CONCLUSIONS AND QUESTIONS}

The ultimate success of Leg 138 will be measured long after the publication of this volume and after much continued research on the material collected. However, with the detailed geographic and temporal sampling completed, combined with the development of a high- resolution stratigraphic framework, we are confident that our understanding of the late Neogene evolution of the eastern equatorial Pacific Ocean has been greatly improved.

However, with the results from Leg 138 come many unanswered questions. One of the biggest changes in sedimentation during the late Neogene is the nearly fivefold decrease in accumulation of biogenic sediments between 6.4 and $3.4 \mathrm{Ma}$. Changes in the pattern of accumulation as well changes in the regional pattern of variability suggest important local ocean circulation changes. The timing makes the closure of the Panamanian Seaway a likely candidate for being an important forcing mechanism. Changes in deep-water chemistry in the basins of the eastern equatorial Pacific also suggest a local effect related to the uplift of this oceanic barrier. However, the global extent of large changes in sediment accumulation requires more than just local tectonic processes. Thus, we are left with the question of how did the global sediment budget change during the late Miocene and early Pliocene? Was it of global extent? Is it a redistribution of biogenic sediments within the ocean system (i.e., basin-shelf fractionation, basin-basin fractionation) or does it represent a major change in chemical fluxes to the ocean system? Based on the limited data, we suggest that the large change in accumulation reflects a change in the global flux of biogenic material to the ocean.

The long paleoclimate time series from Leg 138 provide additional new information about how the variability of the climate system evolved over the late Neogene. But what processes are responsible for the increased sensitivity of the isotopic record to insolation changes at about $4.5 \mathrm{Ma}$ ? The increased variance in the obliquity band since 4.5 Ma appears to be a simple response to increased amplitude in the forcing mechanism. What is the mechanism for the very low-frequency response in the isotope record before about $3 \mathrm{Ma}$ ? In the late Pleistocene, the long time constants of ice sheets and the response of the lithosphere to ice-sheet loading are commonly called upon to account for the low-frequency response of the climate system. Are these processes acting in the early Pliocene when isotopic evidence shows significantly reduced ice sheets? Is the isotopic record dominantly a deepocean temperature proxy at this time? If so, then what long timeconstant processes are responsible for the low-frequency response?

The long time series of carbonate variations in the equatorial Pacific show that solar insolation changes have an important impact on the climate system even before it strongly affects the isotope system. What are the processes responsible for the response of the Pliocene equatorial Pacific carbonate system to insolation changes? Why is this response stronger than that observed in the Pleistocene, when insolation has such a large impact on global climate? Clearly, the complex response of the carbonate and isotope systems during the past 6 m.y. raises many important questions about how Earth's climate system has evolved. Thus, although the Leg 138 data provide many new insights to our understanding of Earth during the late Neogene, much work remains.

\section{REFERENCES}

Archer, D., 1991a. Equatorial Pacific calcite preservation cycles: production or dissolution? Paleoceanography, 6:561-571.

,1991b. Modeling the calcite lysocline. J. Geophys. Res., 96:1703717050.

Barber, R.T., 1992. Fall survey cruise finds cooling conditions in equatorial Pacific. U.S. JGOFS News, 4:1-6.

Barron, J.A., Keller, G., and Dunn, D.A., 1985. A multiple microfossil biochronology for the Miocene. In Kennett, J.P. (Ed.), The Miocene Ocean: Paleoceanography and Biogeography. Mem.-Geol. Soc. Am., 163:2136.

Baumgartner, T.R., and Christensen, N., Jr., 1985. Coupling of the Gulf of California to large-scale interannual variablity. J. Mar. Res., 43:825-848.

\footnotetext{
Abbreviations for names of organizations and publication titles in ODP reference lists follow the style given in Chemical Abstracts Service Source Index (published by American Chemical Society).
} 
Berger, A., and Loutre, M.F., 1991. Insolation values for the climate of the last 10 million years. Quat. Sci. Rev., 10:297-317.

Berger, W.H., 1970. Biogenous deep-sea sediments: fractionation by deep-sea circulation. Geol. Soc. Am. Bull.. 81:1385-1402.

Berger, W.H., Fisher, K., Lai, C., and Wu, G., 1987. Ocean productivity and organic carbon flux, Part I. Overview and maps of primary production and export production. Univ. of California, San Diego, SIO Reference 87-30.

Berger, W.H., Leckie, R.M., Janecek, T.R., Stax, R., and Takayama, T., 1993. Neogene carbonate sedimentation on Ontong Java Plateau: highlights and open questions. In Berger, W.H., Kroenke, L.W., Mayer, L.A., et al., Proc. ODP, Sci. Results, 130: College Station, TX (Ocean Drilling Program), $711-744$.

Berggren, W.A., Kent, D.V., and Van Couvering. J.A., 1985. The Neogene: Part 2. Neogene geochronology and chronostratigraphy. In Snelling, N.J. (Ed.), The Chronology of the Geological Record. Geol. Soc. London Mem., 10:211-260.

Betzer, P.R., Showers, W.J., Laws, E.A., Winn, C.D., Ditullo, G.R., and Kroopnick, P.M., 1984. Primary productivity and particle fluxes on a transect of the equator at $153^{\circ} \mathrm{W}$ in the Pacific Ocean. Deep-Sea Res. Part A, 31:1-11.

Bishop. J.K.B., 1989. Regional extremes in particulate matter composition and flux: effects on the chemistry of the ocean interior. $I n$ Berger, W.H., Smetacek, V.S., and Wefer, G. (Eds)., Productivity of the Ocean: Present and Past. Life Sci. Res. Rep., 44:117-137.

Bohrmann. G., Henrich, R., and Thiede, J., 1990. Miocene to Quaternary paleoceanography in the northern North Atlantic: variability in carbonate and biogenic opal accumulation. In Bleil, U., and Thiede, J. (Ed.), Geological History of the Polar Oceans: Arctic versus Antarctic: Boston (Kluwer), 647-676.

Broecker. W.S., and van Donk, J. 1970. Insolation changes, ice volumes, and the $\mathrm{O}^{18}$ record in deep-sea cores. Rev. Geophys. Space Phys., 8:169-198.

Bryden, H.L., and Brady, E.C., 1985. Diagnostic model of the three-dimensional circulation in the upper Equatorial Pacific Ocean. J. Phys. Oceanogr, 15:1255-1273.

Cox, A., and Engebretson. D., 1985. Change in motion of Pacific plate at 5 Myr BP. Nature, 313:472-474.

Demets, C., Gordon, R.G., Argus, D.F., and Stein, S., 1990. Current plate motions. Geophys. J. Int., 101:425-478.

Dymond, J., and Collier, R., 1988. Biogenic particle fluxes in the equatorial Pacific: evidence for both high and low productivity during the 1982-1983 El Niño. Global Biogeochem. Cycles, 2:129-137.

Emerson, S., and Bender, M.. 1981. Carbon fluxes at the sediment-water interface of the deep-sea: calcium carbonate preservation. J. Mar. Res., 39:139-162.

Farrell, J.W., and Janecek, T.R., 1991. Late Neogene paleoceanography and paleoclimatology of the northeast Indian Ocean (Site 758). In Weissel, J. Peirce, J., Taylor, E., Alt, J., et al., Proc. ODP, Sci. Results, 121: College Station, TX (Ocean Drilling Program), 297-355.

Fischer, K., 1984. Particle fluxes in the eastern tropical Pacific Ocean: sources and processes [Ph.D. thesis]. Oregon State Univ., Corvallis, OR.

Flöhn, H., 1978. Climate and Weather: New York (McGraw-Hill).

France-Lanord, C., Derry, L., and Michard, A., in press. Evolution of the Himalayas since Miocene times: isotopic and sedimentologic evidence from the Bengal Fan. In Treloar, P.J., and Searle, M. (Eds.), Himalayan Tectonics. Geol. Soc. Spec. Publ. London.

Hagelberg, T., Shackleton, N., Pisias, N., and Shipboard Scientific Party, 1992. Development of composite depth sections for Sites 844 through 854 . In Mayer, L., Pisias, N., Janecek, T., et al., Proc. ODP, Init. Repts., 138 (Pt. 1): College Station, TX (Ocean Drilling Program), 79-85.

Haq, B.U., Hardenbol, J., and Vail, P.R., 1987. Chronology of fluctuating sea levels since the Triassic. Science, 235:1156-1167.

Hays, J.D., Imbrie, J., and Shackleton, N.J., 1976. Variations in the Earth's orbit: pacemaker of the ice ages. Science, 194:1121-1132.

Heath, G.R., Rea, D.H., and Levi, S., 1985. Paleomagnetism and accumulation rates of sediments at Sites 576 and 578, Deep Sea Drilling Project Leg 86. western North Pacific. In Heath, G.R., Burckle, L.H., et al., Init. Repts. DSDP, 86: Washington (U.S. Govt. Printing Office), 459-502.

Hey, R., Johnson, G.L., and Lowrie, A., 1977. Recent plate motions in the Galapagos area. Geol. Soc. Am. Bull., 88:1385-1403.

Imbrie, J., Berger, A., Boyle, E., Clemens, S., Duffy, A., Howard, W., Kukla, G., Kutzbach, J., Martinson, D., McIntyre, A., Mix, A., Molfino, B., Morley, J., Peterson, L., Pisias, N., Prell, W., Raymo, M., Shackleton, N., and Toggweiler, J., 1993. On the structure and origin of major glaciation cycles, 2: the 100,000-year cycle. Paleoceanography, 8:699-735.
Imbrie, J., Boyle, E.A., Clemens, S.C., Duffy, A., Howard, W.R., Kukla, G., Kutzbach, J., Martinson, D.G., McIntyre, A., Mix, A.C., Molfino, B., Morley, J.J., Peterson, L.C., Pisias, N.G., Prell, W.L., Raymo, M.E., Shackleton, N.J., and Toggweiler, J.R., 1992. On the structure and origin of major glaciation cycles, 1: linear responses to Milankovitch forcing. Paleoceanography, 7:701-738.

Imbrie, J., and Imbrie, J.Z., 1980. Modeling the climatic response to orbital variations. Science, 207:943-953.

Jenkins, G.M., and Watts, D.G., 1968. Spectral Analysis and Its Applications: San Francisco (Holden Day).

Keigwin, L.D., 1982a. Isotopic paleoceanography of the Caribbean and east Pacific: role of Panama uplift in late Neogene time. Science, 217:350-353. 1982b. Neogene planktonic foraminifers from Deep Sea Drilling Project Sites 502 and 503. In Prell, W.L., Gardner, J.V., et al., Init. Repts. DSDP, 68: Washington (U.S. Govt. Printing Office), 269-288.

Kemp, A.E.S., and Baldauf, J.G., 1993. Vast Neogene laminated diatom mat deposits from the eastern equatorial Pacific Ocean. Nature, 362:141-144.

Klitgord, K.D., and Mammerickx, J., 1982. Northern East Pacific Rise: magnetic anomaly and bathymetric framework. J. Geophys. Res., 87:67256750.

Maier-Reimer, E., Mikolajewicz, U., and Crowley, T., 1990. Ocean general circulation model sensitivity experiment with an open Central American Isthmus. Paleoceanography, 5:349-366.

Mammerickx, J., and Klitgord, K.D., 1982. Northern East Pacific Rise evolution from 25 m.y.B.P. to the present. J. Geophys. Res., 87:6751-6759.

Martinson, D.G., Menke, W., and Stoffa, P.L., 1982. An inverse approach to signal correlation. J. Geophys. Res., 87:4807-4818.

Mayer, L.. Pisias, N., Janecek, T., et al., 1992. Proc. ODP, Init. Repts., 138 (Pts. 1 and 2): College Station, TX (Ocean Drilling Program).

Mayer, L., Theyer, F., Thomas, E., et al., 1985. Init. Repts. DSDP, 85: Washington (U.S. Govt. Printing Office).

Mayer, L.A., 1991. Extraction of high-resolution carbonate data for paleoclimate reconstruction. Nature, 352:148-150.

Mayer, L.A., Shipley, T.H., Theyer, F., Wilkens, R.H., and Winterer, E.L., 1985. Seismic modeling and paleoceanography at Deep Sea Drilling Project Site 574. In Mayer, L., Theyer, F., Thomas, E., et al., Init. Repts. DSDP, 85: Washington, (U.S. Govt. Printing Office), 947-970.

Mayer, L.A., Shipley, T.H.. and Winterer, E.L., 1986. Equatorial Pacific seismic reflectors as indicators of global oceanographic events. Science, 233:761-764.

Mikolajewicz, U., Maier-Reimer, E., Crowley, T.J., and Kim, K.-Y., 1993. Effect of Drake and Panamanian gateways on the circulation of an ocean model. Paleoceanography, 8:409-426.

Milankovitvch, M., 1930. Mathematische Klimalehre und Astronomische Theorie der Klimaschwankungen: Berlin (Gebruder Borntaeger).

Mix, A.C., Rugh, W., Pisias, N.G., Veirs, S., Leg 138 Shipboard Sedimentologists (Hagelberg, T., Hovan, S., Kemp, A., Leinen, M., Levitan, M., Ravelo, C.), and Leg 138 Scientific Party, 1992. Color reflectance spectroscopy: a tool for rapid characterization of deep-sea sediments. In Mayer, L., Pisias, N., Janecek, T., et al., Proc. ODP, Init. Repts., 138 (Pt. 1): College Station, TX (Ocean Drilling Program), 67-77.

Molnar, P., England, P., and Martinod, J., 1993. Mantle dynamics, uplift of the Tibetan Plateau, and the Indian Monsoon. Rev. Geophys., 31:357-396.

Mosher, D.C., Mayer, L.A., Shipley, T.H., Winterer, E.L., Hagen, R.A., Marsters, J.C., Bassinot, F., Wilkens, R.H., and Lyle, M., 1993. Seismic stratigraphy of the Ontong Java Plateau. In Berger, W.H., Kroenke, L.W., Mayer, L.A., et al., Proc. ODP, Sci. Results, 130: College Station, TX (Ocean Drilling Program), 33-49.

Pace, M.L., Knauer, G.A., Karl, D.M., and Martin, J.M, 1987. Primary production, new production and vertical flux in the eastern Pacific Ocean. Nature, 325:803-804.

Peterson, L.C., Murray, D.W., Ehrmann, W.U., and Hempel, P., 1992. Cenozoic carbonate accumulation and compensation depth changes in the Indian Ocean. In Duncan, R.A., Rea, D.K., Kidd, R.B., von Rad, U., and Weissel, J.K. (Eds.), Synthesis of Results from Scientific Drilling in the Indian Ocean. Geophys. Monogr., Am. Geophys. Union, 70:311-333.

Pisias, N.G., and Moore, T.C., Jr., 1981. The evolution of Pleistocene climate: a time series approach. Earth Planet. Sci. Lett., 52:450-458.

Pisias, N.G., Murray, D.W., and Roelofs, A.K., 1986. Radiolarian and silicoflagellate response to oceanographic changes associated with the 1983 El Niño. Nature, 320:259-262.

Pisias, N.G., and Prell, W.L., 1985. Changes in calcium carbonate accumulation in the Equatorial Pacific during the late Cenozoic: evidence from HPC Site 572. In Sundquist, E.T., and Broecker, W.S. (Eds.), The Carbon Cycle 
and Atmospheric $\mathrm{CO}_{2}$ : Natural Variations Archean to Present. Geophys. Monogr., Am. Geophys. Union, 32:443-454.

Prell, W.L., and Kutzbach, J.E, 1992. Sensitivity of the Indian monsoon to forcing parameters and implications for its evolution. Nature, 360:646650.

Raymo, M.E., 1994. The Himalayas, organic carbon burial, and climate in the Miocene. Paleoceanography, 9:399-404.

Ruddiman, W.F., Cameron, D., and Clement, B.M., 1987. Sediment disturbance and correlation of offset holes drilled with the hydraulic piston corer: Leg 94. In Ruddiman, W.F., Kidd, R.B., Thomas, E., et al., Init. Repts. DSDP, 94 (Pt. 2): Washington (U.S. Govt. Printing Office), 615-634.

Schultheiss, P.J., and McPhail, S.D., 1989. An automated $P$-wave logger for recording fine-scale compressional wave velocity structures in sediments. In Ruddiman, W., Sarnthein, M., et al., Proc. ODP, Sci. Results, 108: College Station, TX (Ocean Drilling Program), 407-413. [*]

Shackleton, N.J., Backman, J., Zimmerman, H., Kent, D.V., Hall, M.A., Roberts, D.G., Schnitker, D., Baldauf, J.G., Desprairies, A., Homrighausen, R., Huddlestun, P., Keene, J.B., Kaltenback, A.J., Krumsiek, K.A.O., Morton, A.C., Murray, J.W., and Westberg-Smith, J., 1984. Oxygen isotope calibration of the onset of ice-rafting and history of glaciation in the North Atlantic region. Nature, 307:620-623.

Shackleton, N.J., Berger, A., and Peltier, W.R., 1990. An alternative astronomical calibration of the lower Pleistocene timescale based on ODP Site 677 Trans. R. Soc. Edinburgh: Earth Sci., 81:251-261.

Shackleton, N.J., and Shipboard Scientific Party, 1992. Sedimentation rates: toward a GRAPE density stratigraphy for Leg 138 carbonate sections. In Mayer, L., Pisias, N., Janecek, T., et al., Proc. ODP, Init. Repts., 138 (Pt. 1): College Station, TX (Ocean Drilling Program), 87-91.

Suess, E., 1980. Particulate organic carbon flux in the oceans: surface productivity and oxygen utilization. Nature, 288:260-263.
Theyer, F., Mayer, L.A., Barron, J.A., and Thomas, E., 1985. The equatorial Pacific high-productivity belt: elements for a synthesis of Deep Sea Drilling Project Leg 85 results. In Mayer, L., Theyer, F., Thomas, E., et al., Init. Repts. DSDP, 85: Washington (U.S. Govt. Printing Office), 971-985.

Toggweiler, J.R., Dixon, K., and Broecker, W.S., 1991. The Peru upwelling and the ventilation of the south Pacific thermocline. J. Geophys. Res., 96:20467-20497.

van Andel, T.H., Heath, G.R., and Moore, T.C., Jr., 1975. Cenozoic history and paleoceanography of the central equatorial Pacific Ocean: a regional synthesis of Deep Sea Drilling Project data. Mem.-Geol. Soc. Am., 143.

Vincent, E., 1981. Neogene carbonate stratigraphy of Hess Rise (central North Pacific) and paleoceanographic implications. In Thiede, J., Vallier, T.L., et al., Init. Repts. DSDP, 62: Washington (U.S. Govt. Printing Office), 571-606.

Wright, J.D., Miller, K.G., and Fairbanks, R.G., 1991. Evolution of modern deepwater circulation: evidence from the late Miocene Southern Ocean. Paleoceanography, 6:275-290.

, 1992. Early and middle Miocene stable isotopes: implications for deepwater circulation and climate. Paleoceanography, 7:357-389.

Wyrtki, K., 1966. Oceanography of the eastern equatorial Pacific Ocean. Oceanogr. Mar. Biol. Ann. Rev., 4:33-68.

1967. Circulation and water masses in the eastern equatorial Pacific Ocean. Int. J. Oceanol. Limnol., 1:117-147.

1974. Equatorial currents in the Pacific 1950-1970 and their relations to trade winds. J. Phys. Oceanogr., 4:372-380.

Date of initial receipt: 20 July 1994

Date of acceptance: 5 January 1995

Ms 138SR-101 